\title{
DOENÇAS NEGLIGENCIADAS, POBREZA E EXCLUSÃO SOCIAL: MERA COINCIDÊNCIA GEOGRÁFICA?
}

\author{
NEGLECTED DISEASES, POVERTY AND SOCIAL EXCLUSION: A MERE GEOGRAPHIC \\ COINCIDENCE?
}

Thana Cristina de Campos*

\begin{abstract}
Resumo:
Tem-se como esteio teórico o Direito ao Desenvolvimento, conceituado ampliativamente por Amartya Sen como síntese de todos os Direitos Humanos. Ressalvam-se a pobreza e a exclusão social como obstáculos à efetivação desse Direito ao Desenvolvimento, dentro do qual se insere o Direito à Saúde. As Doenças Negligenciadas são ilustradas como conseqüência dos obstáculos que se erguem ao Desenvolvimento, após verificada a coincidência entre a geografia dessas moléstias e o mapa da Pobreza e da Exclusão Social Mundiais. Sublinha-se a importância da Licença Compulsória de fármacos para a realização do Direito de Acesso a Medicamentos e, por extensão, do Direito à Saúde, realçando-se tal edifício jurídico como exceção legal aos direitos patentários, como instrumento legítimo de política pública de saúde e como meio poderoso para a realização do Direito ao Desenvolvimento. Finalmente, sugere-se a possibilidade de responsabilização, na seara internacional, de agentes governamentais e não-governamentais face aos imperativos direitos humanos.
\end{abstract}

Palavras-Chave: Doenças Negligenciadas. Pobreza. Exclusão Social. Licença Compulsória de Medicamentos. Direito ao Desenvolvimento.

\begin{abstract}
:
The theoretical background is the Right to Development, broadly conceived by Amartya Sen as the synthesis of all the human rights. The poverty and the social exclusion are underlined as obstacles to the realization of such Right to Development, in which the Right to Health is included. The Neglected Diseases are illustrated as consequences of the obstacles to the development, after verifying the coincidence between the geography of such diseases and the global map of poverty and social exclusion. It stresses the importance of the Compulsory Licensing of medicines to the realization of the Right to Access to Medicines and, consequently, the Right to Health, emphasizing such juridical instrument as a legal exception to the patent law, as a legitimate instrument of public health policy and a powerful way to concrete the Right to Development. Finally, it suggests the possibility of responsibility, in the international field, of governmental and non-governmental agents, in light of the imperatives human rights.
\end{abstract}

Keywords: Neglected Diseases. Poverty. Social Exclusion. Compulsory Licensing of Medicines. Right to Development.

\footnotetext{
Bacharel e Mestra em Direito Internacional pela Faculdade de Direito da Universidade de São Paulo. Pesquisadora do Núcleo de Estudos da Violência - NEV/USP.
} 
1. Introdução

A partir da constatação da justaposição existente entre a geografia das Doenças Negligenciadas e o mapa da pobreza e da exclusão social mundiais, o presente trabalho tem como escopo a demonstração de que a negação do Direito Humano Fundamental à Saúde, reflexo dos aludidos fenômenos da Pobreza e da Exclusão Social, permite cogitar uma possível responsabilização internacional dos agentes governamentais e não-governamentais (em especial, as empresas farmacêuticas transnacionais), cujas ações violam os imperativos do direito universal à saúde. Afinal, o preço abusivo dos fármacos, capaz de inviabilizar seu acesso, cumulado com a temática da insuficiência ou inexistência de Pesquisa e Desenvolvimento - P\&D para as doenças negligenciadas, face ao ínfimo interesse econômico que despertam, ensejam a tomada de consciência mundial para crise do acesso à saúde, como negação a um direito humano elementar.

Para tanto, trabalha-se preliminarmente o esteio teórico do Direito ao Desenvolvimento (dentro do qual se insere o Direito à Saúde) ressalvando-se os fenômenos da Pobreza e Exclusão Social Mundiais como obstáculos à sua realização. Da mesma sorte, as Doenças Negligenciadas são caracterizadas como um impedimento à efetivação do Direito à Saúde e do Direito ao Desenvolvimento, motivo pelo qual sua geografia coincide com o mapa de distribuição da Pobreza e da Exclusão pelo globo.

Ato contínuo, a constatação da reprodução dos fenômenos da Pobreza e da Exclusão (explicitada pelas Doenças Negligenciadas) através do agir estratégico de agentes governamentais e não-governamentais (farmacêuticas transnacionais, para o tema em apreço) desperta a atenção para a possibilidade de uma responsabilização internacional desses entes, pela violação ao Direito à Saúde que perpetuam mediante suas ações políticoeconômicas descomprometidas com os princípios basilares de Direitos Humanos.

2. O conceito de direito ao desenvolvimento e a pobreza como um obstáculo à sua efetivação

Para Amartya Sen, ${ }^{1}$ o desenvolvimento consiste na eliminação de todas as formas de privação de liberdade, que limitam as escolhas e as oportunidades dos indivíduos. Em outras palavras, Sen defende a remoção das principais origens da privação de liberdade do ser humano, quais sejam, a pobreza, a tirania, a falta de oportunidades econômicas, a destituição social sistemática, a negligência dos serviços públicos e a intolerância ou interferência excessiva dos Estados repressivos. A pobreza, para o economista indiano, não se resume à escassez de renda, muito embora reconheça que essas informações a

SEN, Amartya. Desenvolvimento como Liberdade. São Paulo: CIA das Letras, 2002. p. 10. 
respeito do nível de renda de uma população sejam relevantes para a compreensão do fenômeno.

Amartya Sen reitera, nesse sentido, que a análise e a compreensão do fenômeno da pobreza não podem ser limitadas apenas ao conceito matemático, quantitativo ou econométrico da renda, sugerindo particular atenção para a liberdade ou a capacidade dos indivíduos de viverem adequadamente, ${ }^{2}$ isto é, viverem conforme um modelo digno, por eles próprios socialmente idealizado. Assim, para Sen, ${ }^{3}$ a pobreza consiste na inadequação dos meios econômicos de que dispõem as pessoas para a geração de suas capacidades minimamente aceitáveis e para a sua realização em sociedade. Não pode ser a pobreza, portanto, considerada como uma categoria isolada, definida por uma análise puramente de medições. Abrange a pobreza todo um contexto sistêmico. ${ }^{4} \mathrm{Ou}$ seja, a pobreza deixa de ser identificada tão-somente como um patamar inferior a um dado nível de renda preestabelecido, ${ }^{5}$ passando a ser concebida como sinônimo de privação de liberdades e capacidades básicas. ${ }^{6}$

Ressalte-se que a pobreza, segundo a conceituação multifacetada ${ }^{7}$ de Sen, permite uma análise mais abrangente também do processo de Desenvolvimento. Aliás, o

2 Em outras palavras, significa dizer que a renda é fundamental para afastar a pobreza, mas o estabelecimento de um critério único e objetivo para a fixação de quem pertence ou não a essa faixa social conduz a resultados equivocados por recusar o reconhecimento das diferenças pessoais, face à existência de indivíduos diversos, inseridos em contextos sociais díspares. Nesse sentido, possível seria a hipótese de existência de um pessoa que se situasse fora da linha de pobreza desenhada, mas que, de fato, viesse a ser mais pobre, sofrendo mais severas limitações a suas liberdades, do que uma pessoa de menor renda, com menor demanda por determinados recursos. Afinal, nas palavras de (SEN, Amartya. Desenvolvimento como liberdade. São Paulo: CIA das Letras, 2002. p. 111), a privação relativa de rendas pode resultar em privação absoluta de necessidades.

3 Id. Ibid., p. 112.

4 Corroborando esse entendimento, para DESTREMAU, B. The systemic relations of the State and poverty. Amman: University of Bergen, CROP, 1999. Disponível em: <http://www.crop.org/publications/ files/newsletter/Newsletter_1999_4.pdf>. Acesso em: 08 jul. 2006), a pobreza é parte de um sistema social, econômico e político, pertencendo a esse sistema realidades, fatos, relações sociais, discursos e representações.

5 Corroborando esse entendimento, AZAM, G. Economie sociale: quel pari? Economie et Humanisme, n. 347, dec. 1998/jan. 1999, p. 16), assevera não se reduzir a pobreza a mero aspecto material ou ainda a um mero sub-consumo determinado por rendimentos insuficientes. Importa dizer, nesse esteio, que uma abordagem unidemensional não se presta para definir a pobreza em sua totalidade.

6 Ressalte-se que a ONU (PNUD. Poverty Report 2000: overcoming human poverty, p. 20.

Disponível em <http://www.undp.org/povertyreport/ENGLISH/ARfront.pdf $>$. Acesso em: 08 de jul. 2006, igualmente utiliza a expressão pobreza humana nessa exata medida, conceituando-a como a ausência de capacidades básicas humanas: analfabetismo, subnutrição, redução da expectativa de vida, saúde maternoinfantil deficitária, doenças de males que podem ser prevenidos. Os critérios indiretos são ausência de acesso a bens, serviços e infra-estrutura - energia, saneamento básico, educação, comunicações, água potável - necessários para sustentar as capacidades básicas humanas.

7 A abordagem multifacetada da pobreza permite evidenciar suas condições e conseqüências, como um processo de negações múltiplas, que apresenta sete clivagens principais, quais sejam, (i) a penúria de rendimentos e de patrimônio; (ii) a inferioridade social; (iii) o isolamento; (iv) a fraqueza física decorrente da subnutrição e de doenças; (v) a vulnerabilidade e a insegurança; (vi) a sazonalidade do trabalho, dos rendoimentos, da 
próprio conceito jurídico hodierno de Desenvolvimento é igualmente multifacetado, dentro da inteligência do Direito ao Desenvolvimento, como direito-síntese de todos os Direitos Humanos fundamentais. Assim, ressalvando-se a interdependência e indivisibilidade dos Direitos Humanos, poder-se-ia falar em uma visão ampliativa não só da pobreza, mas também do desenvolvimento, condicionando ambos os conceitos à realizabilidade de todos os Direitos Humanos fundamentais, dentre os quais a saúde, objeto da presente análise.

Sen reitera a necessidade de uma análise integrada das atividades econômicas, sociais e políticas, ressalvando o indivíduo como um agente ativo da mudança e não como mero sujeito passivo das alterações planejadas por uma instância governamental superior. A liberdade é, assim, um requisito fundamental do desenvolvimento. A liberdade é identificada, nesse esteio, como o meio e o fim do desenvolvimento; e as escolhas realizadas pelos indivíduos dependem, em grande medida, das liberdades políticas, das oportunidades econômicas e das condições sociais (como a educação básica e a saúde adequada) que habilitam as pessoas a concretizarem suas metas. Por outro lado, essas liberdades políticas, essas oportunidades econômicas e essas condições sociais são igualmente influenciadas pelo exercício da liberdade dos indivíduos, seja na participação das escolhas sociais, seja na tomada de decisões públicas. ${ }^{8}$

A pobreza e o desenvolvimento, portanto, devem ser compreendidos como conceitos multifacetados, levando-se em consideração a interdependência de suas instâncias econômicas, sociais e políticas. Como elemento central de sua análise interdisciplinar, Sen parte da noção de liberdade e, sob esse paradigma, afirma que a privação de liberdade econômica pode gerar a privação de liberdade social ou política, assim como a privação de liberdade social ou política, pode gerar a privação da liberdade econômica. ${ }^{9}$

Esse mesmo raciocínio pode ser utilizado na fundamentação da legitimidade da utilização da licença compulsória de medicamentos pelos países em desenvolvimento, em defesa do acesso a medicamentos e, por extensão, na concretização do direito humano à saúde. Afinal, a inexistência de liberdade econômica dos países em desenvolvimento para que se utilizem da licença compulsória justifica-se pela forte pressão político-econômica exercida pelas farmacêuticas multinacionais e pelos países desenvolvidos. Tal inexistência

\footnotetext{
alimentação, a humilhação; e (vii) a ausência de poder nos âmbitos público e privado. (SACHS, I. S’attaquer aux raciness de l’exclusion. In: BRISSET, C. (Org). Pauvretés. Paris: Hachete, 1996. p. 41).

8 Observe-se que a contribuição de A. Sen vai muito além do alargamento do conceito de pobreza. Ao postular a relevância da liberdade e da capacidade como clivagens essenciais do conceito, reconhece a educação, a saúde, o bem-estar, o auto-respeito e a participação na esfera pública como fins em si mesmos e não como instrumentos para outros fins, conforme exarado pelo Relatório do Banco Mundial (SKIRBEKK, G. A. St. Clair. A philosophical analysis of the World Bank's conception of poverty. Disponível em: <www.crop.org. wdasun.htm>. Acesso em: 01 jul. 2006).

9 SEN, Amartya. op. cit., p.23
} 
de liberdade econômica conduz à privação da liberdade social, consubstanciada na negação do Direito de Acesso a Medicamentos/Direito à Saúde.

Frise-se, por derradeiro, que Sen, em inequívoco diálogo com Arendt ${ }^{10}$ vê o desenvolvimento como um processo coletivo de transformação da sociedade, tendo o indivíduo papel central na condução das mudanças, que vão além da produção econômica, alcançando também os demais espectros das relações sociais existentes. Esse processo de transformação geraria uma dilação das liberdades formais e materiais dos indivíduos, possibilitando o desenvolvimento de suas potencialidades, o que repercute nas potencialidades de seus pares, dentro de um ciclo virtuoso. Tal permitiria, no mínimo, o exercício das liberdades essenciais por todos os homens, como a liberdade de nãopassar fome, de não-morrer durante a infância, de ter acesso à educação básica e à saúde adequada.

\section{A negação do direito à saúde como vertente da pobreza e da exclusão social}

Segundo o magistério de Ernst-Ultrich Petersmann, ${ }^{11}$ os Direitos Humanos são os instrumentos legais essenciais de que dispõem os indivíduos em defesa de sua liberdade, contra os abusos de poder. Os Direitos Humanos são, portanto, o arrimo legal que torna imperativa a regulação das relações nacionais e internacionais, de modo a garantir a máxima promoção de uma liberdade eqüitativa e uma autodeterminação individual e coletiva. Os Direitos Humanos atuam harmonizando os conflitos de Direito Público e Privado, estabelecendo limites mais precisos às liberdades individuais, aos direitos de propriedade e às diretrizes constitucionais sobre o poder governamental. Nessa exata medida, a conceituação dos Direitos Humanos como direitos inalienáveis e inerentes a todo indivíduo é condição fundamental para que sejam respeitadas a liberdade, a igualdade e a participação no exercício do poder público e na distribuição dos bens coletivos. ${ }^{12}$

\footnotetext{
${ }_{10}$ ARENDT, Hannah. Origens do Totaliotarismo - Anti-Semitismo, Imperialismo, Totalitarismo. São Paulo: CIA das Letras, 2004. p. 300-336.

${ }^{11}$ Since every individual and every government risk abusing their freedom and powers, and rules do not enforce themselves, human rights are the most important legal instrument for empowering individuals to defend their equal liberties against abuses of power and for forcing governments and also international organizations, to regulate national and international relations in a way promoting maximum equal liberty and individual and collective self-government under the rule of law. Just as economic market competition forces producers to increase their productivity and efficiency for the benefit of consumers, and benefit of their citizens, human rights promote the mutual balancing of conflicting rights and an ever more precise specification of the limits of individual freedoms and property rights and of the Constitutional limitations of governmental powers (PETERSMANN, Ernst-Ultrich. Human rights and international economic law in the 21ST Century - The need to clarify their interrelationships. Journal of International Economic Law, Oxford University, p. 10, 2001).

${ }^{12}$ Human rights are not only universal moral entitlements deriving from respect of the moral autonomy, rationality, and 'dignity' of human beings. They have also become recognized in national constitutions and worldwide
} 
O Direito à Saúde é, nessa medida, introduzido não-somente como direito social, mas, sobretudo, como direito humano fundamental, tutelado em diplomas legais domésticos ${ }^{13}$ e internacionais, ${ }^{14}$ que reiteram a importância das políticas públicas para sua efetivação. Todavia, cumpre salientar que é a advocacia em saúde pública um instrumento da sociedade, não-limitado, portanto, à atuação do Estado em seu dever de garantia à proteção dos Direitos Humanos. Significa dizer que é legítima e desejável a intervenção dos cidadãos e das entidades não governamentais, na busca da realizabilidade dos Direitos Humanos.

Frise-se, por oportuno, que a Organização Mundial da Saúde - OMS, no preâmbulo de seu Acordo Constitutivo, de 26 de julho de 1946, reconhece a saúde como direito humano, conceituando-a como o completo bem-estar físico, mental, social e não apenas como a ausência de doença ou de outros agravos. ${ }^{15}$ Dessa sorte, o acesso a medicamentos essenciais identifica-se como uma das vertentes da realização do direito à saúde, consubstanciando-se, igualmente, como um direito social e humano fundamental, merecendo tutela integral do Estado. Visa, portanto, o direito de acesso a medicamentos à prevenção, ao tratamento ou à cura da patologia então diagnosticada, mediante o fornecimento de fármacos, especialmente quando se explicita a insuficiência econômica do paciente. ${ }^{16}$ Ou seja, fica, então, a questão da gratuidade do medicamento adstrita à capacidade econômica do doente, ressalvando-se que mesmo aqueles que detêm meios

and regional international law as inalienable 'birth rights' of every individual to legally protected freedom, equality, and participation in the exercise of governmental powers and the distribution of collective 'public goods'. (PETERSMANN, Ernst-Ultrich. Human rights and international economic law in the 21ST Century - The need to clarify their interrelationships. Journal of International Economic Law, Oxford University, p. $13,2001)$.

${ }^{13}$ No âmbito da legislação brasileira, há que se citar os arts. $6^{\circ}, 196,197,227, \S 1^{\circ}$, da $/ 88$.

${ }^{14}$ No âmbito internacional, cite-se o art. XXV da DUDH, de 1948, bem como o art. 12 do Pacto Internacional de Direitos Econômicos, Sociais e Culturais, de 1966.

15 DALlARI, S. G. Os Estados brasileiros e o direito à saúde. São Paulo: Hucitec, 1995. p. 19-20. Disponível em: <www.dhnet.org.br/educar/redeedh/bib/dallari3.htm>. Acesso em: 08 jul. 2006.

${ }^{16}$ No Brasil, muitas instituições têm sido questionadas a responder à necessidade de planejamento e efetividade das políticas públicas de acesso à saúde, especialmente por ser este um direito fundamental do cidadão, e pela necessidade de incrementar os métodos de tratamento das doenças que afetam contingentes populacionais necessitados no território nacional. Determinar uma estratégia de incentivo e concretização do acesso à saúde, em qualquer nível que se trate, revela-se um desafio sempre atual. Recentemente, o Ministério da Saúde noticiou a tentativa de estimular negociações entre o governo federal e empresas farmacêuticas para a aquisição de medicamentos a preços diferenciados, bem como a realização de leilões para a compra centralizada de medicamentos, com descontos e preços reduzidos. Vale lembrar que o Brasil contribuiu para o fortalecimento da discussão sobre o acesso a medicamentos essenciais em nível internacional, especialmente no fim da década de 90 , com políticas públicas relacionadas ao tratamento universal das doenças relacionadas ao HIV/AIDS e a campanha pela gratuidade do acesso ao coquetel antiretroviral. Sua repercussão, pelo mérito que teve, chamou a atenção de várias organizações e organismos internacionais e aproximou países em desenvolvimento e em menor desenvolvimento relativo em torno de uma concepção humanitária do acesso à saúde no mundo. (BASSO, Maristela; POLIDO, F. P. Propriedade intelectual e preços diferenciados de medicamentos essenciais: política de saúde pública para países em desenvolvimento, São Paulo, 2004. p. 3). 
razoáveis para a subsistência podem ter o livre acesso a medicamentos essenciais, na hipótese de serem verificados preços abusivos, que inviabilizem o tratamento ou gerem inópia financeira em outras esferas da vida econômica do doente.

Nessa medida, verifica-se a premência na coibição do uso abusivo da propriedade intelectual, direito privado não-absoluto, já que imbuído de uma função social. ${ }^{17}$ Tal assertiva faz-se verdadeira, em especial diante do conflito, imposta pela existência da proteção patentária dos fármacos e a imperatividade do direito à saúde/ acesso a medicamentos. Em outras palavras, de um lado, colocam-se as empresas farmacêuticas que determinam os preços dos medicamentos segundo, dentre outras variantes, os investimentos realizados em P\&D para a elaboração daquele medicamento e a contrapartida do retorno financeiro estimado; de outro lado, coloca-se a população civil mundial que, a despeito da titularidade do direito à saúde, (i) não detém condições financeiras de arcar com os altos custos dos medicamentos; e (ii) vê-se impotente, face à ineficácia ou mesmo inexistência de medicamentos que atendam a doenças tropicais, típicas de países em desenvolvimento. ${ }^{18}$

Imperativo ressalvar ainda que a conflitividade acima mencionada deve ser iluminada pela Teoria da Justiça, de John Rawls, ${ }^{19}$ no sentido da formação de uma nova ordem mundial, voltada a dirimir conflitos sociais, priorizado os mais marginalizados, de modo a favorecer os grupos sociais mais necessitados ou vulneráveis. Afinal, nenhum sistema social, econômico ou político é efetivo, ou, menos ainda, justo, quando constatada a assimetria assustadora, existente entre seus integrantes. Isso explica a premência na

\footnotetext{
${ }^{17}$ Imperativo é observar-se que a função social é a contra-partida do direito de propriedade que explicita ser o direito privado em comento não absoluto, mas sim limitado pelas diretrizes constitucionais. $\mathrm{O}$ direito de propriedade é um direito privado que ganha a tutela ou proteção do Estado, desde que cumprido o requisito da função social. Fala-se, nessa medida, em constitucionalização ou publicização do direito de propriedade. Desse modo, uma vez inobservado o dever da função social pelo proprietário, perde-se a tutela ou proteção constitucional prevista à propriedade.

${ }_{18}$ A esse respeito, asseveram BASSO, Maristela; POLIDO, F. P. Propriedade intelectual e preços diferenciados de medicamentos essenciais: política de saúde pública para países em desenvolvimento. São Paulo: 2004. p. 27), que (...) é justamente nos países mais desenvolvidos que o retorno de investimentos em $P \& D$ revelar-seia mais provável. A decisão por um determinado medicamento, seja ele essencial ou não, normalmente está associada ao tempo de pesquisa, de desenvolvimento da fórmula e sucesso do planejamento. Por isso éque, nem sempre, as empresas atuantes nos países que mais necessitam de politicas de acesso à saúde estarão dispostas a desenvolver, em tão curto periodo de tempo, medicamentos essenciais para o consumo local, destinados ao tratamento de doenças mais freqüentes. Daí porque uma política patentária aplicada à indústria farmacêutica nos países em desenvolvimento e em menor desenvolvimento relativo devem ser constantemente repensadas. Seria indispensável do ponto de vista da proteção dos direitos de propriedade intelectual que seus institutos sejam inadequadamente manipulados, que atendam a exclusividades injustificadas e subaproveitadas.

${ }^{19}$ RAWLS, John. Uma teoria da Justiça. 2. ed. São Paulo: Martins Fontes, 2002. p. 303.
} 
formulação de instituições políticas e jurídicas, voltadas ao atendimento eqüitativo das necessidades humanas básicas. ${ }^{20}$

Dessa feita, o preço abusivo dos medicamentos, capaz de inviabilizar seu acesso, cumulado com a temática da insuficiência ou inexistência de P\&D para as doenças negligenciadas, face ao ínfimo interesse econômico que despertam, ensejam a tomada de consciência mundial para crise do acesso à saúde, pela negação a um direito humano elementar. A pressão civil pública, dessa maneira, deve clamar por uma consistente modificação da estrutura do processo econômico relacionado ao mercado de fármacos essenciais, envolvendo a produção, a distribuição e o consumo das referidas drogas, focalizando questões de enorme relevância humanitária, de modo a influenciar decisões, concretizar projetos e reiterar a legitimidade da utilização das flexibilidades previstas no TRIPS, sempre no sentido de realizar o direito à saúde/acesso a medicamentos.

Reitere-se, por oportuno, que não se trata de ignorar ou anular as diretrizes traçadas pelos direitos privados de proteção patentária, mas sim de harmonizá-las com os imperativos de Direitos Humanos, mediante a implementação dos próprios instrumentos de flexibilidade previstos pelo TRIPS. Implica isso dizer que as exceções aos direitos de propriedade intelectual, explicitadas nos arts. 30 e 31 do TRIPS, permitem um diálogo harmônico entre os direitos de proteção patentária e os Direitos Humanos, particularmente, o direito à saúde, atestando a supremacia desses, em detrimento daqueles, na hipótese de conflito.

Corroborando esse raciocínio, cite-se a vasta obra de adensamento de juridicidade - ao gosto de Celso Lafer $^{21}$ - que reforça a realizabilidade dos documentos internacionais anteriormente exarados.

No tocante à ONU - Organização das Nações Unidas, cumpre reiterar a importância de diversas Resoluções exaradas pelo Alto Comissariado, dentre as quais, destaque-se a Resolução n. 2001/31 (Access to Medication in the Context of Pandemics such as HIV/AIDS) que regula o acesso a medicamentos no combate a doenças pandêmicas, tais como a AIDS, incidentes na população de países pobres e em desenvolvimento. É nesse documento que a ONU reconhece definitivamente que o acesso a medicamentos essenciais

\footnotetext{
${ }^{20}$ No tocante à imperatividade da justiça no sistema social, (RAWLS, John. Uma teoria da Justiça. 2. ed. São Paulo: Martins Fontes, 2002. p. 303) lembra que os princípios da justiça se aplicam à estrutura básica e regulam o modo como suas mais importantes instituições se organizam formando um único sistema [...] $O$ sistema social deve ser estruturado de modo que a distribuição resultante seja justa, independente do que venha a acontecer. Para se atingir esse objetivo é preciso situar o processo econômico e social dentro de um contexto de instituições políticas e jurídicas adequadas. Sem uma organização apropriada dessas instituições básicas, o resultado do processo distributivo não será justo. Faltará a eqüidade do contexto.

${ }^{21}$ LAFER, Celso. Resistência e realizabilidade da tutela dos Direitos Humanos no plano internacional no limiar do século XXI. In: AMARAL JR, Alberto do; MOISÉS, Cláudia Perrone. (Orgs). O Cinqüentenário da Declaração Universal dos Direitos do Homem. São Paulo: Edusp, 1999. p. 450.
} 
é um direito humano fundamental, determinando que os Estados se abstenham de decisões que limitem ou neguem as condições de acesso a tecnologias biofarmacêuticas, utilizadas na prevenção ou no tratamento de infecções ou doenças pandêmicas freqüentes na população. Não obstante, prevê igualmente a obrigação de os países elegerem outras medidas, dentro de seu ordenamento jurídico doméstico, em consonância com o Direito Internacional, com o escopo de resguardarem o acesso às aludidas tecnologias biofarmacêuticas, preventivas ou curativas, reiterando, para tanto, a legitimidade da elaboração de políticas públicas adequadas à alocação de recursos que auxiliem o acesso à saúde. ${ }^{22}$

No âmbito da OMPI - Organização Mundial da Propriedade Intelectual -, agência especializada da ONU, por seu turno, sublinhe-se a relevância da WIPO Patent Agenda - Agenda for Development of the International Patent System, lançada em 2001, com o escopo de auxiliar a harmonização legislativa, mediante a divulgação de leis modelos a servirem de standards às leis domésticas de proteção à propriedade intelectual.

No seio da OMS, há que se relembrar não apenas sua densa obra legislativa, a partir da previsão de diversas Resoluções, ${ }^{23}$ mas também o trabalho de pesquisa da Comission on Intellectual Property Rights, Innovation and Public Health, a qual tem desenvolvido estudos a respeito das políticas relacionadas aos direitos de propriedade intelectual, em especial, os incentivos de P\&D e o acesso a drogas essenciais; bem como o esforço do Special Programme for Research and Training in Tropical Desease - TDR, em estimular a P\&D em doenças tropicais negligenciadas. ${ }^{24}$

Finalmente, há que se salientar a importância do terceiro setor, ainda no que concerne à obra de adensamento de juridicidade. ${ }^{25}$ Nesse sentido, cumpre mencionar o trabalho ímpar desenvolvido pelos Médecins Sans Frontièrs - MSF, nas questões de socorro humanitário e acesso a medicamentos. A título ilustrativo, poder-se-ia mencionar

\footnotetext{
${ }^{22}$ BASSO, Maristela; POLIDO, F. Propriedade intelectual e preços diferenciados de medicamentos essenciais: políticas de saúde pública para países em desenvolvimento. Coleção ABIA - Políticas Públicas, Rio de Janeiro, n. 4, p. 10, 2005.

${ }^{23}$ A título ilustrativo, citem-se as Resoluções WHA 55.12 e WHA 55.14, ambas de 18 de maio de 2002; a WHA 56.27 e a WHA 56.30, ambas de 28 de maio de 2003 e a WHA 57.14, de 22 de maio de 2004; todas contendo disposições a respeito do acesso à saúde.

${ }^{24}$ TDR was created in 1975 to stimulate and coordinate international research aimed at developing effective interventions for neglected tropical diseases. The result has been 67 new drugs and other disease control tools, of which 38 are currently being applied in control programmes. A part from several new antimalarials, significant breakthroughs include the development with Merck in the 1980s of ivermectin for the treatment of onchocerciasis, the development in the late 1980s and early 1990s with Marion Merrill Dow (now Aventis) of eflornithine for the treatment of African trypanosomiasis, and the development in 2002 with Zentaris of miltefosine, the first oral drug for the treatment of visceral leishmaniasis. Disponível em: <www.who.in/tdr $>$. Acesso em: 19 out. 2005.

${ }^{25}$ LAFER, Celso. Resistência e realizabilidade da tutela dos Direitos Humanos no plano internacional no limiar do século XXI. In: AMARAL JR, Alberto do; MOISÉS, Claudia Perrone. (Orgs.) O Cinqüentenário da Declaração Universal dos Direitos do Homem. São Paulo: Edusp, 1999. p. 450.
} 
a iniciativa pioneira dos MSF, quando, em 1999, reuniu-se um corpo internacional de especialistas em Saúde que estudariam a temática da P\&D de drogas para moléstias que acometiam indivíduos dos países em desenvolvimento. Formava-se, à ocasião, o Drugs for Neglected Diseases Initiative - DNDI, entidade que reúne institutos públicos de pesquisa de todo o mundo, dentre os quais a Fundação Oswaldo Cruz - Fiocruz, do Brasil.

Diante de todo o exposto, resta demonstrado, pelo adensamento de juridicidade, que o direito à saúde é um direito humano fundamental, e requisito essencial para a efetivação do Direito ao Desenvolvimento, direito humano igualmente fundamental. Isso implica admitir que, na hipótese de negação ao direito à saúde, ergue-se um obstáculo ao Desenvolvimento da Nação, pela piora nas suas condições de pobreza, bem como pela situação de exclusão social que lhe é imposta. O raciocínio em tela pode ser comprovado pelo próprio enunciado da Declaração do Milênio da ONU e das Metas de Desenvolvimento do Milênio, ${ }^{26}$ ambas de 2000, bem como pelas negociações conduzidas em 2002, em Monterrey, na Conferência da ONU para Financiamento do Desenvolvimento. Em ambas as ocasiões, ficava consignada a relevância da liberdade para viver sem miséria, o que, em outras palavras, denota a premência na erradicação da pobreza, como grave problema global contemporâneo.

O vasto compêndio legislativo supramencionado, responsável pelo adensamento de juridicidade, ${ }^{27}$ atesta, pois, a legitimidade da prevalência do direito à saúde/acesso a medicamentos, face à relevância da aquisição e distribuição dos remédios essenciais para a efetivação do Direito ao Desenvolvimento e minoração dos efeitos da pobreza global. Ocorre que a realidade fática não parece comprovar a supremacia dos Direitos Humanos em relação às normas de comércio internacional, que parecem reproduzir a lógica da pobreza e da exclusão social, ao privilegiarem os interesses político-econômicos de atores governamentais (países desenvolvidos) e não-governamentais (particularmente as grandes farmacêuticas multinacionais) ${ }^{28}$ influentes.

Assim, a lógica da pobreza e da exclusão social é explicitada pelo emprego maciço dos recursos, bem como pela política de P\&D das farmacêuticas multinacionais,

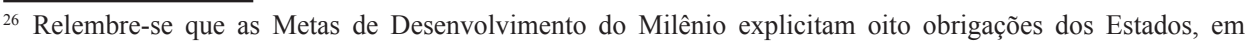
âmbito nacional e internacional, quanto ao desenvolvimento, dentre as quais, motivam o raciocínio em tela: (i) erradicação da pobreza extrema e da fome; (vi) combate ao HIV/AIDS, malária e outras doenças; e (viii) criação de uma parceria global para o desenvolvimento, inclusive com um sistema comercial e financeiro verdadeiramente aberto, previsível, não discriminatório e justo, dispensando atenção especial às vicissitudes dos países em desenvolvimento.

${ }^{27}$ LAFER, Celso. Resistência e realizabilidade da tutela dos Direitos Humanos no plano internacional no limiar do século XXI. cit., p. 450.

${ }^{28}$ LAFER, Celso. O Cenário Mundial e o relacionamento União Européia/Mercosul. Política Externa, v. 9, n. 1, p. 88-91 jun/jul/ago, 2000.
} 
voltados a doenças que atingem, sobretudo, as massas populacionais consumidoras. ${ }^{29}$ Ou seja, as denominadas "doenças negligenciadas" (dentre as quais, cite-se a malária, a tuberculose, a tripanossomíase humana africana (doença-do-sono), a tripanossomíase humana sul-americana (doença de Chagas), a oncocercose, a dengue, a leishmaniose, a lepra, a filariose linfática e a esquistossomose) ${ }^{30}$ recebem parcela ínfima - se não inexistentes - dos investimentos das farmacêuticas transnacionais. Senão, vejamos.

\section{As doenças negligenciadas}

Indubitavelmente, diversos foram os benefícios introduzidos pelo progresso das ciências biomédicas e biotecnológicas, dentre as quais se poderia citar a possibilidade de ampliação da longevidade, bem como a melhora da qualidade de vida do ser humano. Ao lado, todavia, dessa evolução científico-tecnológica, vislumbrada no campo da saúde humana, a manutenção de doenças secularmente conhecidas, ergue-se como mais um incompreensível paradoxo do mundo pós-moderno. É, no mínimo, criticável que enfermidades como a malária, a tuberculose, a tripanossomíase humana africana (doençado-sono), a tripanossomíase humana sul-americana (doença de Chagas), a oncocercose, a dengue, a leishmaniose, a lepra, a filariose linfática e a esquistossomose, que formam um quadro epidemiológico nos países menos desenvolvidos, tenham suas condições agravadas pela total ausência de tratamento ou pela manutenção de tratamentos obsoletos que inviabilizam sua cura. ${ }^{31}$ Trata-se das Doenças Negligenciadas, que, a despeito de afetarem número expressivo de pessoas no globo (conforme se verificará ilustrativamente a seguir), não dispõem de tratamentos eficazes ou adequados para sua prevenção ou cura. Relembre-se que, em casos extremos, inexiste, inclusive, qualquer previsão de tratamento possível.

${ }^{29}$ COMPARATO, Fabio Konder. A afirmação histórica dos Direitos Humanos. 3. ed. São Paulo: Saraiva, 2003. p. 540, a esse respeito, observa que somente $0,2 \%$ das atividades mundiais de pesquisa e desenvolvimento no setor da saúde dizem respeito à pneumonia, à tuberculose e à diarréia, quando se sabe que tais afecções representam 18\% do total das doenças no mundo inteiro. Entre 1975 e 1997, das 1.233 fórmulas medicamentosas patenteadas no mundo, apenas 13 , isto é, pouco mais de $1 \%$, destinavam-se à cura de doenças tropicais, que ceifam anualmente 6 milhões de vidas no mundo.

${ }^{30}$ MSF - Médecins Sans Frontièrs, Patentes de medicamentos em evidência - compartilhando experiência prática sobre patentes de produtos farmacêuticos, maio/2003, p. 5.

MSF - Médecins Sans Frontièrs, Desequilíbrio Fatal - a crise em pesquisa e desenvolvimento de drogas para doenças negligenciadas, set/2001, p. 10-12.

MSF - Médecins Sans Frontièrs, Negociando a Saúde: a propriedade intelectual e o acesso a medicamentos no Acordo da Área de Livre Comércio das Américas (ALCA), ago/2003, p. 10.

${ }^{31}$ Conforme revela a organização MSF (Desequilibrio Fatal - a crise em pesquisa e desenvolvimento de drogas para doenças negligenciadas, set/2001, p.5.), as populações dos países em desenvolvimento correspondem a $80 \%$ da população global, respondendo, todavia, por tão-somente $20 \%$ das vendas mundiais de medicamentos. 
Observe-se, por oportuno, que as doenças negligenciadas são, em sua maioria, enfermidades tropicais infecciosas que afetam especialmente pessoas pobres e excluídas da lógica do consumo da sociedade moderna. Vale dizer, muito embora haja um significativo volume de trabalhos científicos sobre a biologia, imunologia e genética dos parasitas causadores destas moléstias, todo esse conhecimento gerado não é revertido em novas ferramentas terapêuticas para as pessoas afetadas, precisamente porque atingem, sobretudo, as massas populacionais não consumidoras. As aludidas enfermidades têm sido progressivamente marginalizadas pelos programas de pesquisa, essencialmente porque as pessoas acometidas pelas doenças negligenciadas são pobres e não oferecem um retorno lucrativo suficiente para que a indústria farmacêutica invista em P\&D de medicamentos voltados a essas doenças. Com obviedade, portanto, a crise hodierna de falta de medicamentos para doenças negligenciadas não chegou às atuais proporções por falta de conhecimento científico, nem somente pelo hiato entre a pesquisa básica e a pré-clínica. ${ }^{32} \mathrm{~A}$

32 Cumpre esclarecer, nesse tocante que, é a P\&D de medicamentos um processo longo, que se inicia com a pesquisa básica de um novo composto, seguida dos ensaios pré-clínicos, subseqüentemente há os ensaios clínicos, finalizando-se o processo com o registro do medicamento. Cada uma das etapas, frise-se, deve ser plenamente realizada para que se habilite à seguinte. Ademais, observe-se que somente com a conclusão de todas as etapas, chega-se ao produto final, qual seja, o medicamento. Todo o processo ou conjunto de etapas que encerram a $\mathrm{P} \& \mathrm{D}$ de medicamentos é denominado pipeline.

(i) Pesquisa Básica: Trata-se da fase de descoberta, em que os pesquisadores identificam novos compostos que se mostram promissores no combate a alguma patologia. Observe-se, por oportuno, que há um grande número de pesquisadores comprometidos com a pesquisa básica, sobretudo nas Universidades, Institutos e Fundações de Pesquisa. Todavia, há grande dificuldade e falta de incentivos para se passar às demais etapas do pipeline. (ii) Pesquisa Pré-Clínica: Continua-se a investigação, nesse momento mais aprofundada, dos compostos que se mostram promissores durante a fase de pesquisa básica. Nesta fase são verificados os parâmetros de segurança e eficácia da droga, por meio de estudos de toxicidade e de atividade in vitro e em animais in vivo. Sendo o composto aprovado pelos testes em animais, resta comprovada, por conseguinte, sua segurança e eficácia, passando-se então à fase seguinte de testes em seres humanos, denominada Ensaios Clínicos.

(iii) Pesquisa Clínica: Trata-se da fase de desenvolvimento dos medicamentos; consiste em submeter os novos compostos a ensaios clínicos, com o escopo de se avaliar sua segurança e eficácia em seres humanos. Ressalte-se que somente com base nos ensaios clínicos é possível fornecer um dossiê completo de informações necessárias para a obtenção do registro nas agências reguladoras de medicamentos. Os ensaios clínicos são divididos em três fases que representam o estágio de desenvolvimento propriamente dito, e uma quarta fase, denominada farmacovigilância, na qual o medicamento continua sendo avaliado, mesmo após seu registro e lançamento.

(a) Na primeira fase do Ensaio Clínico, busca-se conhecer a tolerância e o metabolismo do medicamento. Para tanto, voluntários sadios recebem doses crescentes da nova substância;

(b) Na etapa subseqüente, um grupo ainda pequeno de pacientes voluntários recebe uma dose determinada da substância. Objetiva-se alcançar a dose ótima, ou seja, aquela em que se verifica o melhor efeito terapêutico, combinado ao menor conjunto de reações adversas;

(c) Ato contínuo, chega-se à fase de estudo piloto, na qual o medicamento é administrado em um número grande de pacientes, variando de dezenas a milhares, a depender do tipo de patologia. Visa-se a avaliar a eficácia e segurança do produto, ressalvando-se que a avaliação é feita comparativamente, utilizando-se um placebo ou um outro tratamento de referência. Ademais, cuidados na utilização e riscos de interação com outras substâncias também são identificados.

(iv) Registro do Medicamento: Habilitando a comercialização e utilização do medicamento pela população, o registro é realizado nas Agências Reguladoras de Medicamentos, a exemplo da Anvisa (Agência Nacional 
atual crise sanitária é o resultado tanto das insuficientes políticas públicas voltadas à $\mathrm{P} \& \mathrm{D}$ de medicamentos de interesse nacional dos países em desenvolvimento, quando da falha de mercado, provocada pelo baixo interesse econômico que esses pacientes representam para a indústria.

Relembre-se ainda que as moléstias são consideradas negligenciadas conforme seus parâmetros de existência, viabilidade e efeitos adversos dos tratamentos a elas direcionados. ${ }^{33}$ Assim, uma enfermidade grave ou letal pode ser considerada negligenciada quando (i) suas opções de tratamento são inadequadas ou inexistem; (ii) quando seu mercado potencial de fármacos é insuficiente para prontamente responder ao anseio de retorno financeiro do setor privado e, por fim, (iii) quando o interesse econômico ou político em tratar esse tipo de doença é insuficiente. Ou seja, há, no caso das doenças negligenciadas, ou uma falha de política pública ou uma falha do mercado.

Diz-se, inclusive, que mais adequada seria a utilização dos termos doenças 'negligenciadas' e 'extremamente negligenciadas', sugerindo uma gradação de sentido. No tocante às doenças 'negligenciadas', verifica-se que o mercado farmacêutico simplesmente ignora os enfermos acometidos por determinadas moléstias, persistentes, sobretudo, em países em desenvolvimento, pelo reduzido interesse econômico ou político de tratamentos. No caso das doenças 'extremamente negligenciadas', vislumbra-se uma situação de proporções ainda mais graves, na medida em que os doentes acometidos vivem sob uma situação de pobreza que não lhes permite deter qualquer poder de compra de fármacos, o que redunda na nulidade absoluta de interesses da indústria farmacêutica

de Vigilância Sanitária), no Brasil, e do FDA (Food and Drug Administration, nos EUA). Para se obter o registro de um produto farmacêutico nessas agências, todas as informações sobre o medicamento e suas fases de desenvolvimento devem ser compiladas em formulários específicos e submetidas às agências para análise e aprovação. Ressalve-se que esse processo pode levar até 3 anos. Saliente-se ainda que cada dose diferente do produto ou cada país diferente onde será utilizado demanda um registro autônomo.

(v) Farmacovigilância: Posteriormente ao registro e lançamento do novo medicamento no mercado, objetivarse-á a identificar reações adversas raras e inesperadas ao medicamento, bem como constantemente traçar a relação custo-benefício do tratamento.

No que concerne às doenças negligenciadas, há três grandes lacunas (gaps) identificadas no pipeline de $\mathrm{P} \& \mathrm{D}$ de medicamentos, que devem ser urgentemente superadas para se conseguir produzir novos medicamentos para seu tratamento. A primeira lacuna coloca-se entra as fases da Pesquisa Básica e Pré-Clínica. Os resultados da Pesquisa Básica são publicados; todavia, a Pesquisa Pré-Clínica, que visa ao desenvolvimento de um novo medicamento, não é iniciada. A segunda lacuna, por sua vez, coloca-se entre as fases das Pesquisas Pré-Clínica e Clínica. Os compostos validados na fase pré-clínica não são conduzidos à fase clínica, por veto econômico-estratégico das empresas farmacêuticas. Finalmente, a terceira lacuna coloca-se posteriormente à fase da Pesquisa Clínica. Os novos medicamentos não chegam até os pacientes por diversas razões, dentre as quais, problemas de registro, produção insuficiente, preços abusivos, produtos mal adaptados às condições locais de utilização.

Disponível em $<\mathrm{http}$ //www.dndi.org.br/Portugues/pesquisa_desenvolvimento_medicamentos.aspx $>$. Acesso em: 08 jul. 2006.

${ }^{33}$ MSF - Médecins Sans Frontièrs, Desequilíbrio Fatal - a crise em pesquisa e desenvolvimento de drogas para doenças negligenciadas, set/2001, p. 8. 
quanto aos seus tratamentos. ${ }^{34 / 35}$ A título ilustrativo, mencionam-se a malária, a tuberculose, a tripanossomíase humana africana (doença-do-sono), a tripanossomíase humana sulamericana (doença de Chagas), a oncocercose, a dengue, a leishmaniose, a lepra, a filariose linfática e a esquistossomose como exemplos de doenças negligenciadas, ressalvandose que todas, salvo as duas primeiras, podem ser consideradas doenças extremamente negligenciadas. ${ }^{36}$

Acrescente-se, outrossim, que é escandalosa a confrontação dos dados estatísticos sobre investimentos em moléstias que acometem intensamente os países desenvolvidos $^{37}$ - e que, por extensão, despertam elevado interesse econômico e político das indústrias farmacêuticas - e os investimentos direcionados aos mercados das doenças negligenciadas - que somam um montante exponencialmente menor. A realidade fática demonstra, infelizmente, que a mitigada atenção que as mazelas em estado de destituição e depauperamento conseguem obter, advém de (i) iniciativas propostas por organizações internacionais, pelo setor público e por organizações não-governamentais, bem como de (ii) algumas parcerias público - privadas, de setores sociais sensibilizados, que buscam atenção da sociedade civil mundial, causando-lhes alguma comoção, a fim de que a impulsionasse a exercer considerável pressão nos setores econômicos e políticos, responsáveis pela $\mathrm{P} \& \mathrm{D}$ de adequados tratamentos.

Nesse esteio, relevante parece tecermos breves comentários acerca de cada uma das aludidas doenças negligenciadas, ilustrando geograficamente a crise sanitária e demonstrando, por conseguinte, que o acometimento das doenças negligenciadas e

\footnotetext{
${ }^{34}$ Vale dizer, no caso das doenças extremamente negligenciadas, nenhuma manipulação das forças de mercado conseguirá estimular o interesse das empresas farmacêuticas a investirem em P\&D dentro desse segmento.

${ }^{35}$ Conforme esclarece o DNDI - Drugs for Neglected Initiative, as Doenças Negligenciadas provocam um interesse apenas marginal na indústria farmacêutica, baseada nos investimentos realizados em P\&D. Embora também afetem indivíduos dos países desenvolvidos, como pacientes com tuberculose e pessoas que contraem malária em viagens, essas moléstias afligem primordialmente as populações dos países em desenvolvimento. As Doenças Extremamente Negligenciadas, por seu turno, afetam exclusivamente as populações dos países em desenvolvimento e de menor desenvolvimento relativo. Como a maioria desses doentes é pobre demais para pagar qualquer tratamento, eles não representam praticamente nenhum mercado e, ficando excluídos do escopo dos esforços de P\&D da indústria de medicamentos e, portanto, fora do mercado farmacêutico. Disponível em: <http://www.dndi.org.br/Portugues/doencas_neglicenciadas.aspx>. Acesso em: 08 jul. 2006.

${ }^{36}$ MSF - Médecins Sans Frontièrs, Desequilibrio Fatal - a crise em pesquisa e desenvolvimento de drogas para doenças negligenciadas, set/2001, p. 8 .

${ }^{37}$ A título exemplificativo poder-se-iam mencionar os altos investimentos direcionados à prevenção e cura de doenças cardiovasculares, das diversas espécies de cânceres, de doenças mentais e distúrbios neurológicos ou, o que é ainda mais escandaloso, o expressivo montante injetado na área da medicina estética. Conforme esclarece o DNDI - Drugs for Neglected Initiative, trata-se das Doenças Globais que representam a maior concentração de $\mathrm{P} \& \mathrm{D}$ da indústria farmacêutica. Apesar de afetarem tanto os países desenvolvidos quanto os em desenvolvimento, nestes a maioria das pessoas que necessitam de medicamentos para tratar essas doenças não pode pagar por elas e, por conseguinte, não é atendida pelo mercado farmacêutico. Disponível em: < http://www.dndi.org.br/Portugues/doencas_neglicenciadas.aspx>. Acesso em: 08 jul. 2006.
} 
extremamente negligenciadas é endêmico ${ }^{38}$ em regiões tropicais do globo, notadamente localizadas em países em desenvolvimento e de menor desenvolvimento relativo, conforme restará explicitado pelos mapas ${ }^{39}$ colacionados a seguir.

(i) Malária ${ }^{40}$

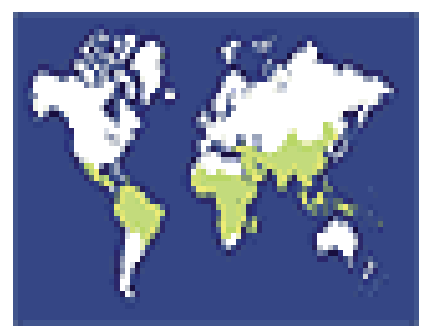

A Malária está presente em mais de 100 países, ameaçando $40 \%$ da população mundial, sendo, porém, especialmente identificada em áreas tropicais e pobres da África, Ásia e América Latina, ressalvando-se que mais de $90 \%$ dos casos de malária que evoluem a óbito ocorrem no continente africano.

Extraído do site da OMS

(ii) Tuberculose $\mathrm{e}^{41}$

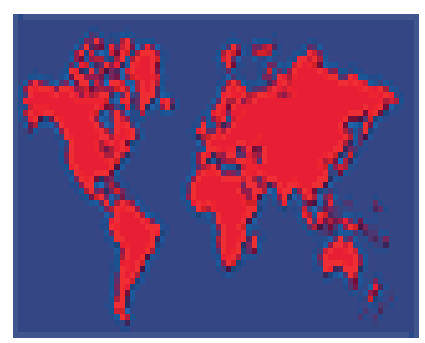

Anualmente, $1 \%$ da população mundial é infectada pela bactéria causadora da Tuberculose. Ressalve-se, porém, que os sintomas só serão manifestados em $5-10 \%$ da população infectada, o que significa dizer que $90-95 \%$ dos infectados apenas portarão a bactéria.

Extraído do site da OMS

Observe-se, a seguir, a porcentagem populacional infectada em cada uma das regiões do globo: Sudeste Asiático: 44\%; África: 35\%; Oceania: 35\%; Leste Europeu: 29\%; Américas: 18\%; Europa: 15\%

\footnotetext{
${ }^{38}$ Ressalve-se, por oportuno, diferenças conceituais existentes entre os termos epidemia, endemia e pandemia. A epidemia é caracterizada pelo abrupto aumento na incidência de uma doença, restrita a um local e a um determinado tempo. Por seu turno, a endemia caracteriza-se pela prevalência de doenças, em um determinado local. Finalmente, a pandemia se caracteriza pelo aumento na incidência de doenças, de modo geograficamente generalizado, isto é, cruzando fronteiras.

${ }_{39}$ Observe-se que todos os mapas ora colacionados encontram-se disponíveis no site da OMS. $<$ http://www.who. $\mathrm{int} / \mathrm{tdr} /$ diseases $>$. Acesso em: 08 jul. 2006.

${ }^{40}$ Disponível em: < http://www.who.int/tdr/diseases/malaria/diseaseinfo.htm>. Acesso em: 08 jul. 2006.

${ }^{41}$ Disponível em: < http://www.who.int/tdr/diseases/tb/diseaseinfo.htm>. Acesso em: 08 jul. 2006.
} 
(iii) Tripanossomíase Humana Africana (Doença-do-Sono) ${ }^{42}$

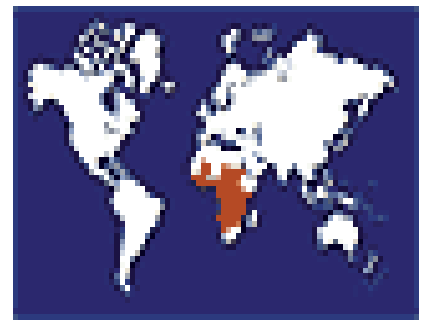

Extraído do site da OMS

Em 1999, 45 mil casos da moléstia em apreço foram reportados pela OMS. Todavia, em realidade, provável é que 300 a 500 mil pessoas tenham sido de fato infectadas. A doença-do-sono ameaça mais de 60 milhões de indivíduos em 36 países da África Sub-saariana, embora menos de seus 4 milhões de habitantes tenham acesso a um centro de saúde.

(iv) Tripanossomíase Humana Sul-Americana (Doença de Chagas) ${ }^{43}$

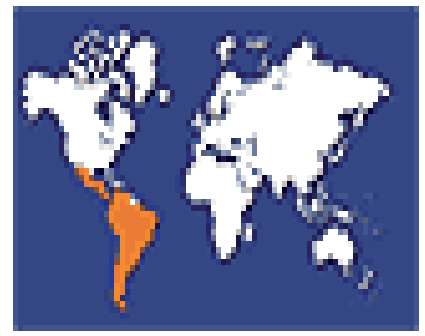

A tripanossomíase americana, ou Doença de Chagas, como foi batizada pelo médico brasileiro que a descreveu no limiar do século XX, é corriqueiramente diagnosticada em todos os 17 países das Américas Central e do Sul, desde o México até o Chile, ameaçando um quarto da população latino-americana.

Extraído do site da OMS

Estima-se que 18 milhões de pessoas estejam vivendo com o parasita no sangue e cerca de 100 milhões de indivíduos estejam sob risco de infecção no território da Américas Latina. Frise-se que as pessoas mais expostas à Doença de Chagas são as mais pobres, que habitam em casas de pau-a-pique, habitat ideal para os insetos vetores do parasita. A Doença de Chagas mata aproximadamente 50 mil pessoas por ano no continente americano, sendo a terceira enfermidade tropical mais prevalente, logo após a malária e a esquistossomose.

\footnotetext{
42 Disponível em: <http://www.who.int/tdr/diseases/tryp/diseaseinfo.htm>. Acesso em: 08 jul. 2006.

43 Disponível em: <http://www.who.int/tdr/diseases/chagas/diseaseinfo.htm>. Acesso em: 08 jul. 2006.
} 


\section{(v) Oncocercose $\mathrm{e}^{44}$}

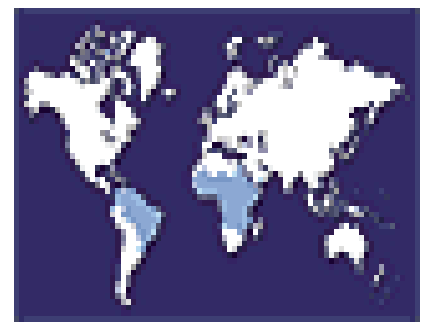

Extraído do site da OMS

A Oncocercose ou "Cegueira dos Rios" acomete um total de 35 países, sendo 28 deles localizados na África Tropical, onde vivem 99\% das pessoas infectadas. Ademais, áreas isoladas de 6 países da América Latina, além do Yêmen também são consideradas localidades endêmicas.

(vi) Dengue ${ }^{45}$

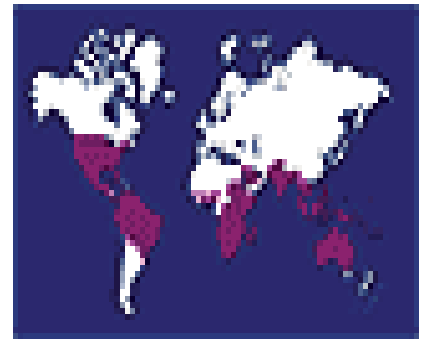

Extraído do site da OMS

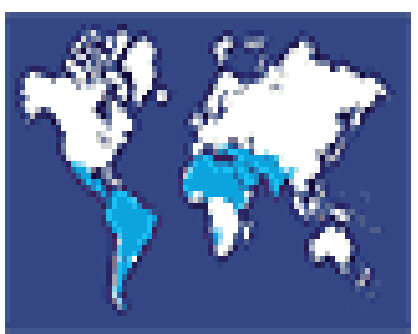

Extraído do site da OMS

Podem ser contabilizados 100 países endêmicos do mosquito transmissor da Dengue, ao longo das Américas, do Sudeste Asiático, Oceania, África e Oriente Médio.

A Leishmaniose Viceral ou Calazar persiste hoje em áreas muito pobres, remotas e, por vezes, politicamente instáveis, onde dificultado é o acesso médico. Os pacientes têm, por essa razão, pouco ou nenhum acesso a medicamentos a preços acessíveis e medidas preventivas.

Trata-se de uma moléstia endêmica em 88 países, nos quais 350 milhões de pessoas estão sob risco de infecção. Sublinhe-se que quase todos os 500 mil novos casos

\footnotetext{
${ }_{44}$ Disponível em: <http://www.who.int/tdr/diseases/oncho/diseaseinfo.htm>. Acesso em: 08 jul. 2006.

${ }^{45}$ Disponível em: < http://www.who.int/tdr/diseases/dengue/diseaseinfo.htm>. Acesso em: 08 jul. 2006.

${ }^{46}$ Disponível em: <http://www.who.int/tdr/diseases/leish/diseaseinfo.htm>. Acesso em: 08 jul. 2006.
} 
anuais são provenientes de epidemias recorrentes e ocorrem nas áreas rurais do continente indiano (Índia, Nepal, Bangladesh), Brasil, e Sudão.

(viii) Lepra $^{47}$

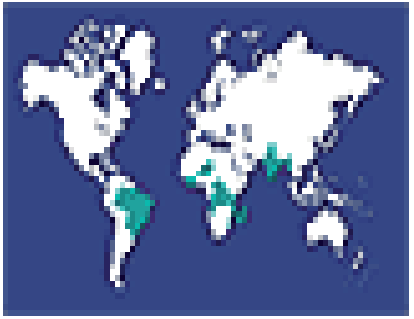

Extraído do site da OMS

(ix) Filariose Lifática ${ }^{48}$

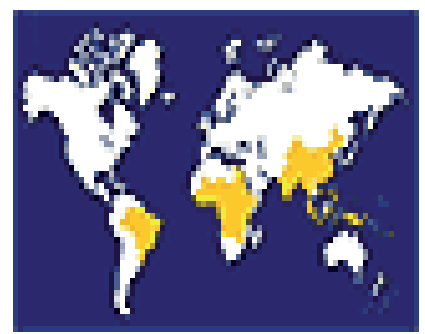

Extraído do site da OMS

\section{(x) Esquistossomose $\mathrm{e}^{49}$}

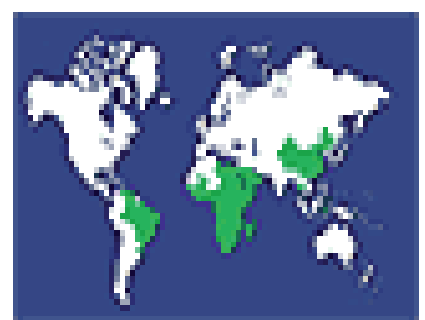

A Esquistossomose atinge uma larga área endêmica, compreendendo 74 países em desenvolvimento da África, Ásia e América Latina, ressalvando-se que mais de $80 \%$ da população infectada habita a África Sub-saariana.

As áreas endêmicas da Filariose Linfática espalham-se por 80 países da África, Ásia, América Latina e Ilhas do Pacífico, ressalvando-se que mais de $40 \%$ da população infectada habita a Índia e 30\%, a África.

A Lepra atinge 15 países e territórios da África, Ásia e América Latina. Ressalve-se, no entanto, o grande progresso já alcançado, relembrando-se que, em 1985, registravam-se 122 países endêmicos da moléstia.

\section{India e $30 \%$, a Atica.} infectada habita a África Sub-saariana.

Extraído do site da OMS

\footnotetext{
47 Disponível em: $<$ http://www.who.int/tdr/diseases/leprosy/diseaseinfo.htm>. Acesso em: 08 jul. 2006.

48 Disponível em: $<$ http://www.who.int/tdr/diseases/lymphfil/diseaseinfo.htm>. Acesso em: 08 jul. 2006.

49 Disponível em: <http://www.who.int/tdr/diseases/schisto/diseaseinfo.htm>. Acesso em: 08 jul. 2006.
} 
Diante de todo o exposto, permite-se, em resumo, realizar as seguintes considerações.

Indubitavelmente a proteção patentária é um efetivo instrumento de incentivo à $\mathrm{P} \& \mathrm{D}$ de novos fármacos, sendo, por conseguinte, mecanismo essencial para a realização do direito à saúde/acesso a medicamentos. Todavia, questiona-se se os investimentos realizados pelas farmacêuticas multinacionais estão sendo destinados a verdadeiramente promover uma melhoria nas condições de saúde da população mundial mais necessitada, que, vivendo sob condições de miséria e depauperamento, é acometida pelas doenças tropicais negligenciadas.

Corroborando esse entendimento, a OMS comprova numericamente a reprodução da lógica da pobreza e da exclusão social, promovida pelas ações estratégicas das indústrias farmacêuticas. Nesse sentido, escandaloso é verificar que, dos 1.223 novos fármacos desenvolvidos entre 1975 e 1996, somente 11 eram destinados ao tratamento de doenças tropicais. ${ }^{50}$ Falha, portanto, a economia de mercado, quando se trata de assegurar P\&D farmacêutico adequados à realização do direito de acesso a medicamentos, por negligenciar uma série de doenças graves e, por vezes, letais, que acometem significativa parcela da população mundial, impedida de exercer seu direito fundamental à saúde.

Imperativa, destarte, parece ser a formação de um forte envolvimento do setor público, articulando um efetivo instrumento de pressão que reúna a sociedade civil, atores governamentais e não-governamentais, com o escopo de se gerar alguma sensibilização pública ao problema, obstando a reprodução da lógica da pobreza e da exclusão social, a impor barreiras à realização do direito à saúde e do direito ao desenvolvimento.

No entanto, para a formulação de adequadas e eficientes políticas corretoras da situação de pobreza e exclusão social hoje existentes, necessário se faz, preliminarmente, precisar os aludidos conceitos, para que sejam hábeis a esvaziar sua lógica de reprodução, num momento posterior de concretização. Senão, vejamos.

\section{A pobreza e a exclusão social}

Havendo um contexto de pobreza e exclusão social, violador de Direitos Humanos fundamentais, notadamente dos direitos econômicos, sociais e culturais, o Direito adquire papel essencial para a modificação dessa situação, de modo a promover maior igualdade. Todavia, a despeito de a pobreza e a exclusão social, manifestações da

\footnotetext{
${ }^{50} \mathrm{OMS}, \mathrm{WHO} / \mathrm{EDM} / 2001.2:$ Globalization, TRIPS and access to pharmaceuticals, WTO Policy Perspectives on Medicines, n. 3, March, 2001, World Health Organization, p. 5-6. Disponível em: <www.who.int/medicines/ pdf/trade6paper.pdf $>$. Acesso em: 08 jul. 2006.
} 
desigualdade, ${ }^{51}$ ocuparem pensadores sociais de todo o globo, é necessário que o Direito atente para as particularidades e vicissitudes peculiares que se revelam no País, as quais não permitem a simples transposição de teses, teorias e definições cunhadas de realidades distintas da brasileira. Corroborando esse entendimento, relembre-se o magistério de Celso Furtado, ${ }^{52}$ no sentido de que é impossível imaginar-se um modelo ideal de desenvolvimento, posto que cada nação possui suas particularidades históricas, que tornam as meras importações dos modelos institucionais dos países desenvolvidos grandes fracassos. A atenção às especificidades contextuais dos países em desenvolvimento é, nessa medida, relevante na arquitetura de seu processo de desenvolvimento. ${ }^{53}$ Diferentes graus de efetividade da democracia, dos direitos sociais e da assistência social, bem como distintos níveis de desenvolvimento e variadas concepções culturais justificam as particularidades de cada Nação e impedem a mera incorporação de teorias e conceitos uniformizantes.

Não-obstante, para o fim de se alcançar a plena efetividade das normas de políticas públicas de proteção contra a pobreza e a exclusão social, deve o Direito conceituar precisamente a situação de pobreza. Aliás, a inexistência de um exato conceito jurídico de pobreza no ordenamento jurídico brasileiro contribui para a inadequação das diversas políticas públicas brasileiras, fundamentadas tão-somente em critérios contingenciais, face à inexistência de um parâmetro objetivo. Assim, a definição de um conceito jurídico de pobreza e exclusão social afigura-se indispensável a uma tentativa verdadeira de correção da desigualdade, característica do Brasil, mediante a arquitetura de adequadas políticas públicas sociais e econômicas.

\section{Aspectos conceituais da pobreza}

O termo "pobreza" pode ser definido como plurívoco e, dessa feita, vago e impreciso. Observa Rajni Kothari ${ }^{54}$ que a pobreza pode ser analisada segundo seu sentido político, econômico, jurídico, social ou psicológico. No que concerne especificamente a sua acepção econômica, recorrentemente evocada, a pobreza é definida como a falta ou insuficiência de recursos monetários, que possibilitem sua conversão em bens e direitos necessários a um padrão de vida digno. Se, de um lado, a noção de pobreza como escassez de recursos mostra-se excessivamente reducionista, a multiplicidade, a vagueza e a

\footnotetext{
51 ARZABE, P. H. M. O direito à proteção contra a pobreza e a exclusão social. 2001. Tese (Doutorado) - São Paulo, Universidade de São Paulo, 2001. p. 1

${ }^{52}$ FURTADO, Celso. O mito do desenvolvimento econômico. Rio de Janeiro: Paz e Terra, 1994.

${ }^{53}$ Ainda nesse tocante, relembre-se a redação do art. $1^{\circ}$ do Pacto sobre Direitos Econômicos, Sociais e Culturais, de 1966, explicitador do direito à autodeterminação, no sentido de que cada Estado é soberano na determinação de seu sistema econômico e social.

${ }^{54}$ KOTHARI, R. Poverty - human consciousness and the amnesia of development. London: Zed Books, 1993. p. 90.
} 
indefinição de seu conteúdo, por outro lado, impedem a construção de políticas públicas adequadas e eficientes.

Dessa feita, mister se faz a pausa para pensar o conceito de pobreza. Nesse particular, alguns foram aqueles que se ocuparam da tarefa de tentar definir a pobreza. Citese, primeiramente, Jose Bengoa, ${ }^{55}$ que relembra a existência de um conceito subjetivo e implícito de pobreza, intuitivamente compreendida por todos os indivíduos. Por seu turno, Jacques Fierens ${ }^{56}$ salienta a comunicação entre os termos "pobreza" e "precariedade", ambos causadores de circunstâncias de necessidade, humilhação e exclusão, apesar de sublinhar que aludidos termos não podem ser tidos exatamente como sinônimos.

Conforme anteriormente mencionado, a acepção econômica de pobreza, abordagem reducionista, embora dominante, elege as perspectivas da renda e do consumo, definindo um dado padrão ou nível mínimo de recursos como determinantes - ou-não - da pobreza. O âmbito de análise renda-consumo separa os indivíduos em duas categorias, a saber, aqueles que possuem o suficiente para subsistir e aqueles que não possuem, sendo, portanto, pobres. Valendo-se dessa perspectiva, o Banco Mundial - $\mathrm{BM}^{57}$ houve por bem fixar os valores de renda equivalente a U\$ 1,00 (um dólar) por dia, como a linha definidora dos indivíduos que vivem sob condições de extrema pobreza (lower poverty line), e a U\$ 2,00 (dois dólares) diários, como o limite identificador de pessoas que viviam sob uma situação mais elevada de pobreza (upper poverty line). Analogamente, o Brasil adota o critério da cesta calórica para definir a pobreza extrema, a partir do traçado da linha de fome. ${ }^{58}$ Assim, de acordo com esse juízo, a indigência corresponderia ao valor de $25 \%$ do salário mínimo, ao passo que a pobreza equivaleria a 50\% desse mesmo montante. Observese, todavia, que o critério em apreço é utilizado apenas para finalidades estatísticas. Para a condução de programas de seguridade social e de combate à pobreza, o Brasil vale-se dos mais variados critérios, eleitos conforme a conveniência e oportunidade política, o que dificulta enormemente a articulação das políticas públicas de proteção contra a pobreza.

Atente-se, todavia, para o fato de que o critério em comento é dotado de objetividade meramente aparente, na medida em que não reflete verdadeiramente as situações de pobreza e desigualdade do Brasil, por ignorar diferenças regionais,

\footnotetext{
55 BENGOA, Jose. Pobreza e vulnerabilidad. Temas Sociales, Santiago, n. 10, p. 2, abr. 1996.

${ }^{56}$ FIERENS, Jacques. Droit et pauvreté: droits de l'homme, securité sociale, aide sociale. Bruxelas: Bruylant, 1992. p. 18

${ }^{57}$ BM, World Development Report 2000/2001 - attacking poverty, p. 17-18 e 320. Disponível e m: <ht tp://web.worldbank.org/W B S T E/EXTERNAL/TOPICS/EXTPOVERTY/ 0, contentMDK:20195989 pagePK:148956 piPK:216618 theSitePK:336992,00.html>. Acesso em: 15 jul. 2006.

${ }^{58}$ A linha de fome corresponde ao valor da renda mensal individual necessária para satisfazer as necessidades básicas alimentares, ou seja, corresponde ao custo do mínimo calórico para a sobrevivência humana.
} 
culturais $^{59}$ e econômicas de um País de escala continental, caracterizado pela diversidade antropológica.

Verifica-se, então, com clareza, a inexistência, no Brasil, de um conceito jurídico objetivo de "pobreza", termo, aliás, definido politicamente, seja para fins e manipulações estatísticas, seja para a formulação de políticas públicas, conforme o critério da conveniência e oportunidade de seus formuladores. ${ }^{60}$ Blandine Destremau $^{61}$ ressalta que o discurso público sobre a pobreza é um ato público, que visa a galgar o controle social e a legitimidade das ações governamentais, perpassando a manipulação das mensurações da extensão e profundidade da pobreza. Afinal, se em determinadas circunstâncias um número elevado de pobres pode ser percebido como uma falha do Poder Público, incapaz de promover os direitos fundamentais desses indivíduos marginalizados, em outras circunstâncias, a mesma situação pode contribuir para a imagem de um País pobre e fragilizado, perante a comunidade internacional, necessitado de investimentos e empréstimos a custo reduzido, na tentativa de se reverter tal situação de carência.

\section{A pobreza absoluta $v s$ a pobreza realtiva}

A distinção conceitual ora apresentada faz-se relevante para a atividade prática do Poder Público, em sua função de arquitetar adequadas políticas públicas, não podendo ser classificada, portanto, como mera discussão conceitual alheia à realidade. Tratando dos diferentes graus de destituição e depauperamento, é a distinção conceitual em apreço fundamental para a definição de políticas públicas que respondam prioritariamente aos indivíduos cujo estado sócio-econômico seja mais abjeto. Nesse sentido, discrimina-se a pobreza absoluta da pobreza relativa. Senão, vejamos.

A pobreza absoluta, também apelidada pobreza extrema, é, segundo o BM, ${ }^{62}$ designada como a privação da dignidade humana, caracterizada por fome, má nutrição, entornos esquálidos, doenças, alta mortalidade infantil, baixa expectativa de vida, analfabetismo, inexistência de um local adequado para habitação e de vestuário

\footnotetext{
${ }_{59}$ Nesse tocante, (BENGOA, Jose. op. cit., p. 2) critica o conceito de pobreza absoluta, como aquela em que a pessoa não pode alimentar-se com o mínimo suficiente para sua manutenção fisiológica, na medida em que a antropologia já demonstrou a relatividade do conceito de mínimos fisiológicos, determinados não só biológica, mas culturalmente também, o que comprova a natureza política e relativa do conceito de pobreza.

${ }^{60}$ ARZABE, P. H. M. op. cit., p. 9

${ }^{61}$ The systemic relations of the State and poverty, Amman, University of Bergen, CROP, 1999. Disponível em: $<\mathrm{http}: / /$ www.crop.org/piblications/files/newsletter/Newsletter_1999_4.pdf>. Acesso em: 08 jul. 2006.

${ }^{62}$ BM, World Development Report 2000/2001 - attacking poverty, p. 15. Disponível e m: <http://web.worldbank.org/W B SITE/EXTERNAL/TOPICS/EXTPOVERTY/ 0,,contentMDK:20195989 pagePK:148956 piPK:216618 theSitePK:336992,00.html>. Acesso em: 15 jul. 2006.
} 
apropriado. Para a ONU, ${ }^{63}$ a pobreza absoluta ou extrema teria um sentido mais estrito, ${ }^{64}$ equivalente à indigência ou à miséria, vez que seria caracterizada pela falta de recursos suficientes à satisfação das necessidades alimentares básicas.

O conceito da pobreza relativa, também denominada pobreza geral (overall poverty), por sua vez, permite explicitar certas nuances ou variações que seriam ignoradas sob as considerações absolutas da pobreza extrema, vez que realiza comparações entre a população pobre e seus pares. Tal noção pode ser verdadeiramente útil quando aplicada aos países desenvolvidos ou em desenvolvimento, como instrumento de verificação da desigualdade social, quer em âmbito doméstico, quer internacional. ${ }^{65}$ Afinal, os indivíduos classificados como pobres, em relação à riqueza de seus próximos, podem estar em situação confortável se comparados aos pobres de outra região ou de outro país. A pobreza relativa permite, portanto, indicar a camada social que, a despeito de não ser indigente ou miserável, por ter acesso a bens e serviços que lhe garantem uma vida digna, vivem em condições bem inferiores a seus semelhantes.

Ainda no que concerne ao conceito de pobreza relativa, o $\mathrm{BM}^{66}$ define, segundo parâmetros de consumo e não mais de renda, a linha da pobreza relativa, equivalente a um terço do consumo médio mundial, explicitando a distribuição de renda para as diferentes regiões. Nessa medida, 15\% da população latino-americana encontrarse-ia abaixo da linha da pobreza extrema, vivendo com apenas U\$ 1,00 (um dólar) por dia; ao passo que 50\% desse mesmo espaço amostral encontra-se abaixo da linha da pobreza relativa, por consumirem menos de um terço do que consome a média global.

\footnotetext{
${ }^{63}$ PNUD, Poverty Report 2000: overcoming human poverty, p. 20. Disponível em: <http://www.undp.org/ povertyreport/ENGLISH/ARchap1.pdf> Acesso em 08 de julho de 2006.

${ }^{64}$ ARZABE, P. H. M. op. cit., p. 10.

${ }_{65}$ O método da pobreza relativa permite claramente demonstrar a desigualdade em dada nação, uma vez que se refere não somente à pobreza per se, mas também à justiça social e à moralidade. Relembra-se que a desigualdade é com freqüência avaliada a partir da desigualdade de renda, medida pelo coeficiente de Gini (variando entre zero e um, indica maior desigualdade quanto mais próximo for o coeficiente de um), o qual permite a comparação entre diferentes sociedades e diferentes épocas.

Nesse tocante, (LAFER, Celso. Liberdade e igualdade: reflexões sobre o crescimento econômico e a democracia. In: Ensaios sobre a Liberdade. São Paulo: Perspectiva, 1980. p. 130-32) destaca a importância de um coeficiente de Gini preferencialmente inferior a 0,4 , como nas sociedades com renda média ou alta, como condição para a democracia. E acrescenta: o crescimento realizado com desigualdade crescente não eliminou ou atenuou, de maneira significativa, o problema da pobreza absoluta, posto que as camadas da população excluidas dos benefícios do crescimento econômico atingem taxas percentuais impressionantes. Observe-se que a afirmação do autor, realizada há mais de duas décadas atrás, permanece verdadeira nos dias de hoje. Tendo em conta que o Brasil está entre as quinze maiores economias do mundo, possível seria concluir que nossa pobreza não deriva da insuficiência da riqueza nacional, mas sim da distribuição risivelmente desigual da renda.

${ }_{66}$ BM, World Development Report 2000/2001 - attacking poverty, p. 24. Disponível em: <http://web.worldbank.org/W B SITE/EXTERNAL/TOPICS/EXTPOVERTY/ 0, contentMDK:20195989 pagePK:148956 piPK:216618 theSitePK:336992,00.html>. Acesso em: 15 jul. 2006.
} 
De acordo com a ONU, ${ }^{67}$ diferentemente, a pobreza relativa é designada não segundo parâmetros de consumo, mas sim de renda, sendo entendida como a falta de recursos necessários à satisfação de necessidades básicas alimentares e não-alimentares, como habitação, vestuário, energia elétrica. Frise-se, por oportuno, que a Organização para Cooperação e Desenvolvimento Econômico - OCDE, ${ }^{68}$ organização internacional de países desenvolvidos, costuma utilizar o parâmetro da renda média da população, a fim de definir o padrão normal de vida e a situação de pobreza. Assim, a linha de pobreza relativa dos países desenvolvidos gravitaria em torno dos 40,50 ou $60 \%$ da renda mediana mundial.

Diante de todos os métodos expostos, há que se realizar algumas considerações. Primeiramente, deve-se atentar para o fato de que é criticável a construção de linhas de pobreza, por não retratarem todas as dimensões do fenômeno. ${ }^{69} \mathrm{O}$ nível de bem-estar dos indivíduos deve ser determinado por um conjunto complexo de fatores psicossociais e não-somente pela renda ou pelo consumo. ${ }^{70}$ Outrossim, constata-se que as políticas públicas, especialmente aquelas voltadas à proteção contra a pobreza, atingem a população mais próxima da linha de pobreza então estabelecida, que detém ao menos algum conhecimento ou algum patrimônio sob a forma de moradia ou terra para uso agropastoril. Ocorre que as políticas públicas em comento acabam por ignorar a população que se encontra sob as mais severas condições de destituição e depauperamento, não raro desprovidas, inclusive, de documentos que lhes garantam sua inclusão em programas sociais. $^{71}$

Em suma, é desejável que o conceito político e jurídico de pobreza seja objetivamente definido, conforme o padrão de desenvolvimento que se deseja publicamente ao País. O critério do mínimo calórico adotado pelo Brasil hodiernamente, além de ser indigno por não refletir coerentemente as necessidades humanas, compromete a imagem internacional do País, em um projeto de nação que eventualmente se pretenda

\footnotetext{
67 PNUD. Poverty Report 2000: overcoming human poverty, p. 19. Disponível em: <http://www.undp.org/ povertyreport/ENGLISH/ARchap1.pdf>. Acesso em: 08 jul. 2006.

68 Trata-se de uma organização internacional formada por 30 países desenvolvidos, baseada nos princípios da democracia representativa e da economia de livre mercado. A sede da organização encontra-se em Paris, França. Criada em 30 de setembro de 1961, sucede à Organização para a Cooperação Econômica Euroéia,então criada em 16 de abril de 1948. Desde 01 de junho de 2006, seu Secretário-Geral é o mexicano José Ángel Gurría Treviño. Observe-se que, a despeito de o Brasil não pertence à OCDE, desde 1995 participa como membro pleno ou como observador de diversos comitês, dentre os quais os do Aço, de Comércio, da Concorrência, da Agricultura, de Investimentos e Empresas Multinacionais e de Gestão Pública. Disponível em: <http://www. oecd.org/about/>. Acesso em: 08 jul. 2006.

69 ARZABE, P. H. M. op. cit., p. 11.

${ }^{70}$ LOPES, H. M.; MACEDO, P. B. R.; MACHADO, A. F. Indicador de pobreza: aplicação de uma abordagem multidimensional ao caso brasileiro. In: Texto para Discussão n. 223. Belo Horizonte: UFMG/Cedeplar, 2003. Disponível em: <http://www.cedeplar.ufmg.br/pesquisas/td/TD\%20223.pdf>. Acesso em: 08 jul. 2006.

71 ARZABE, P. H. M. op. cit., p. 11.
} 
consolidar. ${ }^{72}$ Conforme observa Patrícia H. M. Arzabe, ${ }^{73}$ a implementação de políticas públicas de enfrentamento à pobreza não terá êxito sem um direito envolvimento das políticas econômicas internas e internacionais. É exatamente nesse particular que se insere a temática da importância do comércio internacional para o desenvolvimento das nações, tocando, especificamente a questão da licença compulsória de medicamentos como legítimo instrumento de política pública doméstica e internacional, a garantir o Direito à saúde da população mais marginalizada, sem acesso a medicamentos essenciais.

\section{As causas da pobreza}

Se a pobreza, conforme enunciada por Sen, ${ }^{74}$ consubstancia-se em um processo multifacetado, ${ }^{75}$ correto também parece o entendimento de que as causas desse processo sejam igualmente múltiplas, moldadas por um contexto político, jurídico, econômico e social que interagem entre si. A ONU, ${ }^{76}$ da mesma forma, enumera como as maiores causas da pobreza no Brasil: a persistência da desigualdade e a distribuição desigual dos gastos sociais em saúde, educação e seguro-desemprego, a privilegiarem as classes média e alta. Nesse sentido, reconhece o $\mathrm{BM}^{77}$ que, nos locais onde o poder político é distribuído desigualmente, de maneira a encobrir uma distribuição desigual também do poder econômico - nítida ilustração do Brasil - provável é que as políticas públicas ajam de modo não-favorável aos pobres. Ocorre que, conforme observa Arzabe, ${ }^{78}$ BM evita reconhecer o papel fundamental exercido pelos agentes governamentais e não-governamentais mais influentes, a saber, os países desenvolvidos, as empresas multinacionais (em especial as farmacêuticas, para nosso caso particular de análise) e as instituições financeiras, na geração, manutenção e aprofundamento da pobreza.

${ }_{72}$ ARZABE, P. H. M. op. cit., p. 12.

73 Id. Ibid., p. 14

74 SEN, Amartya. Desenvolvimento como liberdade. São Paulo: CIA das Letras, 2002. p. 112.

75 A abordagem multifacetada da pobreza permite evidenciar suas condições e conseqüências, como um processo de negações múltiplas, que apresenta sete clivagens principais, quais sejam, (i) a penúria de rendimentos e de patrimônio; (ii) a inferioridade social; (iii) o isolamento; (iv) a fraqueza física decorrente da subnutrição e de doenças; (v) a vulnerabilidade e a insegurança; (vi) a sazonalidade do trabalho, dos rendoimentos, da alimentação, a humilhação; e (vii) a ausência de poder nos âmbitos público e privado. (SACHS, I. S’attaquer aux raciness de l’ exclusion. In: BRISSET, C. (Org.). Pauvretés. Paris: Hachete, 1996. p. 41).

${ }^{76}$ PNUD. Poverty Report 2000: overcoming human poverty. p. 20. Disponível em: <http://www.undp.org/ povertyreport/ENGLISH/ARchap1.pdf>. Acesso em: 08 jul. 2006.

77 BM, World Development Report 2000/2001 - attacking poverty, p. 1. Disponível e m: <http://web.worldbank.org/WB SITE/EXTERN A L/ TOPICS/EXTPOVERT Y / 0, contentMDK:20195989 pagePK:148956 piPK:216618 theSitePK:336992,00.html >. Acesso em: 15 jul. 2006. p. 1.

78 ARZABE, P. H. M. op. cit., p. 21. 
Diante disso, permite-se consignar que a causa primeira da pobreza no Brasil reside precisamente na desigualdade, o que leva a concluir que políticas públicas voltadas exclusivamente à questão da pobreza não conseguirão resolver o problema da desigualdade e da exclusão. Outrossim, ignorar a existência de interesses governamentais e nãogovernamentais - notadamente dos países desenvolvidos e das empresas multinacionais - na manutenção da situação de depauperamento agudiza a eficácia das políticas públicas de proteção contra a pobreza e a exclusão social.

Sublinhe-se, por oportuno, que não se pode olvidar da condição psíquica ou do contexto ideológico da pobreza, que permanece mesmo após a minimização da privação econômica. ${ }^{79}$ Em outras palavras, a baixa auto-estima, associada à pobreza e à precariedade de condições de sobrevivência, conduz a uma indiferença política e social, aprofundando e reproduzindo o processo de marginalização e exclusão social. Nesse sentido, Kothari ${ }^{80}$ observa que a pobreza provoca uma alienação progressiva do pobre, que se vê excluído do entorno da sociedade, pela sensação de a ela não pertencer ou a ela não interessar. Daí se afirma a impertinência de políticas exclusivas de complementação de renda ou programas de renda mínima, que deveriam ser complementados por políticas que possibilitem e ampliem o desenvolvimento de todas as capacidades das pessoas, dentro de seu contexto sócio-cultural.

Nessa exata medida, $\operatorname{Sen}^{81}$ reitera que é exatamente o aumento das capacidades que conduz à ampliação do poder de auferimento de renda e não o avesso. Assim, a melhoria do ensino fundamental e dos serviços básicos de Saúde não apenas melhora diretamente a qualidade de vida dos indivíduos, como também majoram o potencial individual e coletivo de auferir renda e libertar-se da condição de pobreza. Ou seja, quanto maior e mais profunda for a realização da educação básica e dos serviços de Saúde, maior será o incentivo para que os pobres superem sua condição de penúria.

É precisamente nesse esteio que se ressalva, por mais uma vez, a importância da efetivação do Direito à Saúde, particularmente sob o prisma do direito de acesso a medicamentos, como condição essencial a contribuir para a superação da pobreza, obstáculo do desenvolvimento. Obviamente não se está a afirmar que a mera utilização do edifício jurídico da licença compulsória de medicamentos, como legítimo instrumento de política pública de Saúde, seria per se o instrumento suficiente para a superação da pobreza como um processo multifacetado ${ }^{82}$ que é, envolvendo diversas categorias, dentre as quais a Saúde. Está, porém, a afirmar-se que a licença compulsória de medicamentos, na

\footnotetext{
79 KOTHARI, R. Poverty - human consciousness and the amnesia of development. London: Zed Books, 1993. p. 90 .

${ }^{80}$ Id. Ibid., p. 90

81 SEN, Amartya. Desenvolvimento como Liberdade. São Paulo: CIA das Letras, 2002. p. 113.

${ }^{82}$ Id. Ibid., p.23
} 
medida em que compreendida como legítimo instrumento de política pública de Saúde, é automaticamente um poderoso meio para a realização do Direito Humano à Saúde, o qual se consubstancia como uma categoria essencial para a superação da pobreza e condução ao desenvolvimento.

\section{Aspectos conceituais da exclusão social}

Segundo a lição de Kothari, ${ }^{83}$ a pobreza e a exclusão social são feitos distintos, a despeito de integrarem um fenômeno único, igualmente manifestados pelo enfraquecimento (disempowerment) social e político dos indivíduos envolvidos. Vale dizer, a pobreza opera como alicerce da exclusão social. Aqueles com baixa qualificação e escolaridade, sem acesso a serviços básicos de Saúde, subempregados, desempregados há longo tempo, com prole numerosa, ou mesmo mulheres, idosos, negros, índios e migrantes são subclassificados nas relações sociais. À margem do mercado formal de trabalho, determinante para a inserção social, a massa dos excluídos avoluma-se, explicitando a insuficiência ou ausência de mecanismos jurídicos, políticos, sociais e culturais de coesão social.

O conceito de exclusão social extrapola os limites político, econômico, jurídico, social e psicológico da pobreza. ${ }^{84}$ Consubstancia-se em uma situação agravada pelo impedimento de participação social de certos grupos ou categoriais marginalizadas, que constituem relações marcadas pela insuficiência ou ausência de proteção e integração social e, por extensão, pela ausência de Poder. ${ }^{85} \mathrm{~A}$ exclusão social, portanto, seria um obstáculo ao exercício dos Direitos Humanos, tal qual a pobreza, mas que a ela extrapola por também impedir a participação do indivíduo excluído nas principais instituições da sociedade. Nas palavras de Arzabe, ${ }^{86}$ sempre que ocorrem cerceamentos socialmente difusos e sistemáticos de direitos humanos que dificultem a indivíduos, grupos ou categorias o exercício de suas liberdades, de seus direitos políticos, de sua participação na comunidade, bem como seu florescimento como pessoa, enquanto a outros individuos, grupos ou categorias o exercício desses direitos é possibilitado e mesmo facilitado, estaremos defronte a uma situação de desigualdade do tipo que permite ser denominada exclusão social.

\footnotetext{
83 KOTHARI, R. op. cit., p. 85

84 Id. Ibid., p. 90

85 ARZABE, P. H. M. op. cit., p. 36

86 Id. Ibid.
} 
10. As causas da exclusão social

Conforme consignado pela Organização Internacional do Trabalho - OIT, em um projeto de pesquisa a respeito dos tipos e causas da exclusão social, ${ }^{87}$ afirma-se que tal resulta da combinação de três fatores domésticos essenciais, a saber, instituições políticas, sociais e econômicas, ressalvando-se o indubitável papel central do poder de intervenção do Estado nas causas e na permanência da pobreza e da desigualdade. Assim, algumas das causas essenciais da exclusão social estão ligadas (i) à incapacidade de o Estado proporcionar aos seus cidadãos os direitos sociais elementares; (ii) à ineficiência de o Estado gerir os recursos públicos; (iii) ausência de responsabilidade financeira, bem como de planejamento no elenco de prioridades a nortearem o gasto do orçamento público; e, sobretudo, (iv) ao mau funcionamento do sistema político.

Em outras palavras, afirma-se que as instituições públicas em geral (vale dizer, políticas, sociais e econômicas) desempenham um papel fundamental na articulação dos processos de exclusão. Afinal, elas respondem não-só pela estruturação das mudanças econômicas a guiarem o crescimento da nação, como também são responsáveis pelas transformações das condições de vida da população. Destarte, faz a exclusão social parte de um processo político, social e econômico abrangente, não apenas restrito ao âmbito doméstico da Nação, mas também relacionado ao contexto internacional, ${ }^{88}$ pautado

\footnotetext{
${ }^{87}$ Organização Internacional do Trabalho, ISBN 92-9014-587-0, The Patterns and Causes of Social Exclusion, in Social Exclusion and Anti-Poverty Strategies, 1996. Disponível em: <http://www.ilo.org/public/english/ bureau/inst/papers/synth/socex/index.htm\#ch2>. Acesso em: 08 jul. 2006.

${ }^{88}$ Understanding social exclusion involves analyzing this macro-micro relationship. The studies identify a range of macro-processes in which social exclusion is embedded. These include: industrialization; modernization; and transition from a socialist to a market economy; and a historical path of change, which includes urbanization, industrialization and ever closer integration into the world economy.

Organização Internacional do Trabalho, ISBN 92-9014-587-0, The Patterns and Causes of Social Exclusion, in Social Exclusion and Anti-Poverty Strategies, 1996. Disponível em: <http://www.ilo.org/public/english/ bureau/inst/papers/synth/socex/index.htm\#ch2>. Acesso em: 08 jul. 2006.
} 
pelas lógicas da globalização e da fragmentação, ${ }^{89}$ da liberalização econômica ${ }^{90}$ e da thin morality, ${ }^{91}$ para relembrar Lafer.

A OIT é enfática ao reconhecer que a exclusão social em um país não pode ser compreendida sem referência às relações internacionais, vez que são elas causadoras de importantes efeitos sobre as instituições domésticas, sejam elas políticas, sociais ou econômicas. Vale dizer, embora a exclusão social seja efeito direito do poder de intervenção do Estado, a partir de suas instituições públicas, a exclusão social não pode ser simplesmente resumida a fatores internos, na medida em que as relações exteriores estão profundamente relacionas aos acontecimentos internos. ${ }^{92}$

${ }^{89}$ Cumpre relembrar, no magistério de LAFER, Celso. A identidade internacional do Brasil e a política
externa brasileira: passado, presente e futuro. São Paulo: Perspectiva, 2004. p. 109), que a queda do muro
de Berlim consubstancia um marco político ideológico de ruptura, por introduzir um novo paradigma da vida
internacional, até então estruturada conforme as polaridades definidas das relações Leste/Oeste, Norte/Sul.
Assim, o século XX, inaugurado pela desagregação da URSS e pela dissolução dos conflitos de concepção
colocados entre a ideologia Ocidental, em contraposição à ideologia Oriental, caracterizar-se-á por polaridades
indefinidas, sujeitas às 'forças profundas' de duas lógicas que operam numa dialética contraditória de mútua
complementariedade: a lógica da globalização e a da fragmentação. Nesse tocante, cumpre reiterar que
a lógica da globalização pode ser ilustrada pela racionalidade universalizante das finanças, da economia,
da informação, da tecnologia, dos valores, ao passo que a lógica da fragmentação é exemplificada pela
exacerbação das identidades, da secessão dos Estados, dos fundamentalismos e da exclusão social, a que ora
se alude.

${ }^{90}$ Relembre-se que a diluição dos conflitos de concepção explica-se a partir da percepção generalizada de que, em uma economia globalizada, não há desenvolvimento viável a partir de um isolamento autárquico. Tratase, portanto, da consagração dos valores do Liberalismo Econômico, pautado nos valores democráticos. Consolidou-se, por conseguinte, o interesse em normas garantidoras do acesso a mercados, a partir de normas multilaterais do comércio, no seio institucional da OMC (LAFER, Celso. Comercio, desarmamento e Direitos Humanos: reflexões sobre uma experiência diplomática. São Paulo: Paz e Terra. p. 33, 34).

${ }^{91}$ Relembre-se que o conceito de thin morality ou "moralidade rala" é promovido pela lógica da globalização, no campo dos valores. Tal moralidade rala enseja uma limitação no discurso e sobretudo no agir kantiano, voltado aos "interesses gerais". Significa isso dizer que a moralidade rala, a que ora se alude, enseja ações estatais reduzidas a um foco politíco-estratégico, voltado aos interesses locais e nacionais, em detrimento dos valores maiores e universais da Justiça e da Solidariedade. Dessa forma, percebe-se com clareza que o mundo contemporâneo fundamenta seu agir em uma concepção hobbesiana-maquiavelico e, diminuir a prevalência dessa visão dentro da vida internacional é atualmente um imperativo para a possibilidade de ascensão de um mundo grociano, pautado naqueles valores maiores e universais. (LAFER, Celso. O Cenário Mundial e o relacionamento União Européia/Mercosul. Política Externa, v. 9, n. 1, p. 88-91, jun/jul/ago, 2000).

$92[\ldots]$ Social exclusion within countries cannot be explained without reference to international relationships, as these relationships have important effects on domestic economic, social and political institutions.

Although social exclusion within countries is the result of the way in which their economic, social and political institutions are changing and the nature of domestic policies, the studies make it clear that social exclusion cannot simply be attributed to "internal factors". International relationships are increasingly and ever more deeply implicated in what is happening in countries. [...]

Organização Internacional do Trabalho, ISBN 92-9014-587-0, The Patterns and Causes of Social Exclusion, in Social Exclusion and Anti-Poverty Strategies, 1996. Disponível em: <http://www.ilo.org/public/english/ bureau/inst/papers/synth/socex/index.htm\#ch2>. Acesso em: 08 jul. 2006. 
Nessa exata medida, complementa Lafer, ${ }^{93}$ observando que deve ser a política externa entendida como política pública voltada a traduzir necessidades internas em possibilidades externas. O que significa dizer que a política externa, como política pública que é, voltado ao objetivo do desenvolvimento do Brasil, deve igualmente atentar para a minoração dos efeitos da pobreza e da exclusão social, convertendo esses objetivos internos para a linguagem da diplomacia. No caso em tela, em que discutimos a crise sanitária de acesso a medicamentos, cuja gravidade fica patente com a ilustração geográfica das Doenças Negligenciadas, a utilização da licença compulsória de medicamentos mostrase como uma resposta adequada. Trata-se, afinal, de um edifício jurídico hábil a traduzir a necessidade interna do acesso a remédios essenciais em uma legítima possibilidade externa de utilização das flexibilidades previstas no TRIPS.

11. O direito de proteção contra a pobreza e a exclusão social: influência de agentes governamentais e não-governamentais

Não se pode tratar da implementação do direito à proteção contra a pobreza e a exclusão social desconsiderando-se a lógica de funcionamento da economia global, cujos atores de maior relevância são os Estados, as organizações internacionais e as empresas transnacionais. ${ }^{94}$ Está a afirmar-se, portanto, (i) a necessidade da conjugação das políticas sociais às políticas econômicas, com o escopo de se alcançar maior efetividade do direito de proteção contra a pobreza e a exclusão social; e, sobretudo, (ii) a utilização de políticas econômicas como instrumento essencial para a proteção contra a pobreza e exclusão social. Reitere-se, todavia, a necessidade do fortalecimento do Estado, bem como de todas as instituições públicas que abrange, para a concretização dos referidos imperativos.

Frise-se, por oportuno, que a Declaração e Programa de Ação para o Desenvolvimento Social, resultado da Conferencia Mundial para Desenvolvimento Social, ocorrida em Copenhagen, em 1995, já ressaltava que

\footnotetext{
${ }_{93}$ LAFER, Celso. A identidade internacional do Brasil e a Política Externa brasileira: passado, presente e futuro. São Paulo: Perspectiva, 2004. p. 108.

${ }^{94}$ Relembre-se que, para nosso caso particular de análise, verificar-se-ão, especialmente, as ações dos países desenvolvidos, da OMC e das farmacêuticas multinacionais, questionando-se se as políticas econômicas praticadas por esses três aludidos agentes reproduzem e ampliam a pobreza e a exclusão mundial ou, ao contrário, garantem o desenvolvimento dos povos, subordinando suas políticas às diretrizes traçadas pela DUDH. Não parece irreal ou forçoso admitirmos a prevalência dos interesses econômicos, em detrimento dos direitos humanos, o que nos conduz a questionamentos a respeito da responsabilidade internacional desses três agentes econômicos, a saber, os Estados (em especial os desenvolvidos), as organizações internacionais (particularmente a $\mathrm{OMC}$ ) e as empresas transnacionais (notadamente as farmacêuticas multinacionais, para o caso em tela).
} 
o progresso social não será realizado simplesmente pela livre interação das forças de mercado. Políticas públicas são necessárias para corrigir as falhas de mercado, complementar os mecanismos de mercado, manter a estabilidade social e criar um ambiente nacional e internacional que promova o crescimento econômico sustentável em escala global. Tal crescimento econômico deve promover eqüidade e justiça social, tolerância, responsabilidade e envolvimento.

Inegável é a existência de obstáculos a serem transpostos, visando-se à redução da vulnerabilidade das políticas domésticas sociais e econômicas, face à influência política dos poderosos agentes governamentais (países desenvolvidos), organizações internacionais e empresas multinacionais. A temática ora analisada especificamente questiona a influência política exercida pelos países desenvolvidos, bem como pelas farmacêuticas multinacionais, que ao reproduzirem a lógica da fragmentação, ${ }^{95}$ aprofundam os aspectos de pobreza global e exclusão social, ao submeterem os Direitos Humanos, consagrados na Declaração Universal dos Direitos Humanos - DUDH, à prevalência de seus interesses econômicos privados e de seu poder de barganha.

É nesse sentido que Lafer ${ }^{96}$ atenta para a necessidade de se inserir a 'barganha' dos interesses especificos no âmbito da 'argumentação' relativa à promoção dos interesses comuns. Ou seja, patente é a dificuldade hoje enfrentada pelas instituições do multilateralismo (cite-se a ONU, a OMC, a OMS, a OMPI, a UNCTAD, dentre outras) para conter os unilateralismos, governamentais e não-governamentais, que, ao se utilizarem de seu forte poder de barganha, tornam explícitas as relações assimétricas de poder que hoje caracterizam a realidade econômica mundial.

Dessa feita, há de se sugerir uma possível responsabilização internacional de empresas transnacionais e de terceiros Estados na violação dos Direitos Humanos, consagrados na DUDH. Afinal, na medida em que as ações dos agentes não governamentais ou governamentais atingem negativamente os Direitos Humanos - como o direito á saúde, em nosso caso particular de análise - o limite de liberdade de ação será ultrapassado, perdendo sua legalidade e legitimidade.

\footnotetext{
${ }_{95}^{5}$ LAFER, Celso. A identidade internacional do Brasil e a Politica Externa brasileira: passado, presente e futuro. São Paulo: Perspectiva, 2004. p. 109.

${ }^{96}$ LAFER, Celso. O Cenário Mundial e o relacionamento União Européia/Mercosul. Política Externa, v. 9, n. 1, p. 88-91, jun/jul/ago, 2000.
} 
12. A responsabilidade internacional dos Estados e da OMC face ao direito de proteção contra a pobreza e a exclusão social

Importa relembrar que não-somente as empresas multinacionais limitam a capacidade e liberdade dos Estados, em especial os países em desenvolvimento e de menor desenvolvimento relativo, em determinar suas políticas econômicas e sociais de proteção e promoção dos Direitos Humanos. As ações de outros agentes governamentais, notadamente dos países desenvolvidos, igualmente causam consideráveis conseqüências, em se tratando do desrespeito aos Direitos Humanos e piora da situação de pobreza e exclusão social.

Também a atuação da OMC agrava a situação, vez que não consegue neutralizar os unilateralismos praticados pelos Estados de economia forte, que massacram a lógica do multilateralismo, norteadora da organização. ${ }^{97} \mathrm{~A}$ despeito da obra de adensamento de juridicidade - nos dizeres de Lafer $^{98}$ - que reforça a realizabilidade dos documentos internacionais atinentes aos Direitos Humanos, a OMC parece consignar-se como um claro empecilho à efetiva e ampla implementação do direito de proteção contra a pobreza e exclusão social. ${ }^{99}$

Cumpre relembrar, por oportuno, que a OMC explicita no preâmbulo de seu Acordo Constitutivo os objetivos de elevação dos níveis de vida e pleno emprego, além de visar à obtenção de um incremento do comércio internacional que corresponda às necessidades de desenvolvimento econômico, dos países em desenvolvimento e, especialmente, dos países de menor desenvolvimento relativo. Outrossim, reitera no artigo XX do GATT, o rol das exceções gerais ao acordo, que podem ser adotadas pelos Estadosparte, dentre as quais elenca a possibilidade de adoção das medidas necessárias a proteger a vida ou a saúde humana, animal ou vegetal, de inequívoca importância para a proteção dos Direitos Humanos.

A contrário senso, porém, as decisões exaradas pelo Órgão de Solução de Controvérsias da OMC cristalizam a inegável prevalência dos interesses comerciais sobre quaisquer outras considerações humanísticas ou sociais, conforme ilustrado pelo caso

\footnotetext{
97 Nessa exata, relembre-se o magistério de Celso Lafer no sentido de que é patente a dificuldade hoje enfrentada pelas instituições do multilateralismo (citem-se a ONU, a OMC, a OMS, a OMPI, a UNCTAD, dentre outras) para conter os unilateralismos, governamentais e não-governamentais, que, ao se utilizarem de seu forte poder de barganha, tornam explícitas as relações assimétricas de poder que hoje caracterizam a realidade econômica mundial. (Id. Ibid.)

98 Resistência e Realizabilidade da Tutela dos Direitos Humanos no Plano Internacional no Limiar do Século XXI. In: AMARAL JR, Amaral. do; MOISÉS, Claudia Perrone. (Orgs.). O Cinqüentenário da Declaração Universal dos Direitos do Homem, São Paulo, Edusp, 1999, p. 450.

99 ARZABE, P. H. M.op. cit., p. 288.
} 
Beef Hormone (WT/DS26), ${ }^{100}$ em que o direito à saúde e à vida são colocados em risco pela liberdade de iniciativa econômica. A aplicação dos acordos firmados no seio da OMC podem, portanto, influenciar negativamente os direitos e deveres jurídicos de os Estados protegerem e promoverem os Direitos Humanos, notadamente o direito à saúde e o direito de proteção contra a pobreza e a exclusão social. ${ }^{101}$

Destarte, ainda que o Órgão de Solução de Controvérsias da OMC cristalize o entendimento de que o GATT não deva ser lido isoladamente, o artigo XX do mesmo acordo expressamente prevê que o Estado tem autonomia soberana em matéria de interesse público, medidas de proteção à saúde pública e de realização ao direito à saúde, ainda que isso possa converter-se em prejuízos a obrigações comerciais outrora firmadas. ${ }^{102}$ A conseqüência que emerge das interpretações exaradas pelos panels da OMC, porém, evidencia os obstáculos colocados à liberdade de escolha, à implementação dos direitos sociais, notadamente do direito de proteção contra a pobreza e a exclusão social, instrumento do direito ao desenvolvimento, como direito-síntese de todos os Direitos Humanos. Triste é, pois, a constatação, a partir do panorama exposto, do quão frágil é ainda o discurso internacional da efetiva proteção dos Direitos Humanos.

\section{A responsabilidade internacional das empresas multinacionais}

No momento em que a preocupação rigorosa com os lucros, desvinculada de quaisquer considerações éticas, converte-se no exclusivo fim da ação empresarial, as violações aos Direitos Humanos - e ao direito à saúde, inclusive, no caso das farmacêuticas transnacionais - podem efetivar-se sistematicamente nos diversos Estados em que atua o grupo multinacional. Agravam-se, dessa maneira, as situações de pobreza e exclusão social, mediante a negação aos Direitos Humanos pelo agir empresarial estratégico. Indubitavelmente, mecanismos nacionais de proteção e controle são relevantes; são, todavia, ineficientes para coibir práticas empresariais que, ao ultrapassarem fronteiras, enxergam limites apenas na estrutura dos acordos firmados no seio da OMC, o que reitera

\footnotetext{
${ }^{100}$ Trata-se do primeiro caso sob a égide do Acordo sobre Medidas Sanitárias e Fitossanitárias, levado à $\mathrm{OMC}$ pelos EUA, em razão de barreira fitossanitária imposta pela União Européia à importação de carne bovina contendo hormônios, sob o argumento de risco à saúde humana. Ao final, houve o Órgão de Solução de Controvérsias por bem decidir favoravelmente aos EUA, possibilitando-lhes a imposição de sanções comerciais. Para maior detalhamento, consultar: <http://www.wto.org/english/ tratop_e/dispu_e/26arb.pdf\#search='Beef\%20Hormone\%20\%28WT\%2FDS26\%29'>. Acesso em: 08 jul. 2006.

${ }^{101}$ CORREA, C. M. Implementing national health policies in the framework oh the WTO agreements. Journal of World Trade, v. 34, n. 5, p. 90, 2000.

${ }^{102}$ CORREA, C. M. Implementing national health policies in the framework oh the WTO agreements. Journal of World Trade, v. 34, n. 5, p. 94-96, 2000.
} 
a necessidade de fortalecimento dos instrumentos de proteção e controles também no âmbito internacional.

A esse respeito, Chris Jochnick ${ }^{103}$ observa que os instrumentos internacionais de proteção de Direitos Humanos já contemplam deveres aos agentes não-governamentais. Em outras palavras, não-somente aos Estados são previstos deveres de respeito, proteção e promoção dos Direitos Humanos, mas também aos agentes privados. Afinal, a DUDH consubstancia-se em um ideal comum dos povos e nações, sendo objetivo e simultaneamente dever de cada indivíduo e de cada sociedade respeitar, proteger e promover aludidos direitos fundamentais. Nesse esteio, configura-se como um imperativo de Direito Internacional que a proteção aos direitos da pessoa humana sobrepuje os interesses econômicos ou direitos privados (cite-se aqui o exemplo do direito privado patentário dos fármacos, que deve ceder frente à imperatividade de realização do direito de acesso a medicamentos e do direito à saúde, nos casos legalmente previstos no TRIPS).

A despeito, porém, da ausência de adequado e efetivo tratamento à responsabilidade internacional dos agentes não-governamentais, algumas ações judiciais a respeito da violação de Direitos Humanos por empresas transnacionais começam a aflorar pioneiramente na jurisdição norte americana, por força do Alien Tort Claims Act e do Torture Victim Prevention Act. Muito embora a precisa definição dessa legislação estadunidense ainda esteja por se definir na seara dos Direitos Humanos Internacionais, indubitável é a relevância das jurisprudências ${ }^{104}$ por elas ensejadas, como paradigmas à redução das atividades agravantes da pobreza e da exclusão, norteando uma reorientação da conduta de governos e de empresas multinacionais. ${ }^{105}$

Interessante é, todavia, notar um aparente paradoxo no fato de os EUA colocarem-se como o principal opositor à utilização da licença compulsória de medicamentos, como legítimo instrumento de política pública a realizar o Direito Fundamental à Saúde. Tal oposição, relembre-se, sustenta-se pela importância dada pelos EUA aos direitos privados patentários, relevância culturalmente semeada e reiterada pela restrita leitura feita ao TRIPS. Quiçá, essa nova vertente de jurisprudência norteamericana, postuladora de um novo paradigma à orientação da conduta de governos e de empresas multinacionais, em favor dos Direitos Humanos, não venha a abrir um precedente relevante à prevalência do Direito à Saúde, em detrimento do direito patentário?

\footnotetext{
${ }^{103}$ The human rights challenge to global poverty, in The Poverty of Rights - human rights and the eradication of poverty, Willem van Genugten \& Camilo Perez-Bustillo: CROP, 2001. p. 161.

${ }^{104}$ Conforme aponta MUCHLINSKI, P. T. Human Rights and multinationals: is there a problem? International Affairs, 77, I, p. 42, 2001), cumpre citar, nesse esteio, os casos Doe v. Unocal; e Wiwa v. Royal Dutch Petroleum Company and Shell Transport And Trading Company PLC.

${ }^{105}$ ARZABE, P. H. M. op. cit., p. 283.
} 


\section{Conclusão}

O presente trabalho teve como norte teórico o Direito ao Desenvolvimento, conceituado ampliativamente por Amartya Sen como síntese de todos os Direitos Humanos, dentre os quais se insere o Direito à Saúde. Ressalvaram-se a pobreza e a exclusão social como obstáculos à efetivação desse Direito ao Desenvolvimento. As Doenças Negligenciadas foram, nesse sentido, ilustradas como conseqüência dos obstáculos que se erguem ao Desenvolvimento, após verificada a coincidência entre a geografia dessas moléstias e o mapa da Pobreza e da Exclusão Social Mundiais.

Sublinhou-se a importância da Licença Compulsória de fármacos para a realização do Direito de Acesso a Medicamentos e, por extensão, do Direito à Saúde, realçando-se tal edifício jurídico como exceção legal aos direitos patentários, como instrumento legítimo de política pública de Saúde e como meio poderoso para a realização do Direito ao Desenvolvimento.

Finalmente, sugeriu-se a possibilidade de responsabilização, na seara internacional, de agentes governamentais e não-governamentais (em especial, as empresas farmacêuticas transnacionais), face aos imperativos de Direitos Humanos. Partiu-se da premissa de que o Direito à Saúde e o Direito ao Desenvolvimento são imperativos legais. Constatou-se, todavia, sua inobservância, explicitada pelos fenômenos da Pobreza e da Exclusão Social, de que são reflexo as Doenças Negligenciadas. Face a esse paradoxo, cogitou-se a possibilidade da responsabilização internacional desses agentes, cujas ações violam os imperativos do direito universal à saúde.

Afinal, o preço abusivo dos fármacos, capaz de inviabilizar seu acesso, cumulado com a temática da insuficiência ou inexistência de P\&D para as doenças negligenciadas, face ao ínfimo interesse econômico que despertam, ensejam a tomada de consciência mundial para crise do acesso à saúde, como negação a um direito humano elementar e imperioso.

A pressão civil pública, dessa maneira, deve clamar por uma consistente modificação da estrutura do processo econômico relacionado ao mercado de fármacos essenciais, envolvendo a produção, a distribuição e o consumo das referidas drogas, focalizando questões de enorme relevância humanitária, de modo a influenciar decisões, concretizar projetos e reiterar a legitimidade da utilização das flexibilidades previstas no TRIPS, sempre no sentido de realizar o direito à saúde/acesso a medicamentos.

Nesse sentido, relembre-se a licença compulsória de medicamentos como um poderoso mecanismo para a realização do Direito de Acesso a Medicamentos, e, por extensão, do Direito à Saúde. Esclareça-se que tal instrumento jurídico que não pretende inobservar ou anular as diretrizes traçadas pelos direitos privados de proteção patentária, mas sim de harmonizá-las com os imperativos de Direitos Humanos, mediante 
a implementação dos instrumentos de flexibilidade previstos pelo próprio TRIPS. Implica isso dizer que as exceções aos direitos de propriedade intelectual, explicitadas nos artigos 30 e 31 do TRIPS, permitem um diálogo harmônico entre os direitos de proteção patentária e os Direitos Humanos (particularmente, o direito à saúde) atestando a supremacia desses (de ordem pública), em detrimento daqueles (de ordem privada).

No caso em tela, em que discutimos a crise sanitária de acesso a medicamentos, cuja gravidade fica patente com a ilustração geográfica das Doenças Negligenciadas, a utilização da licença compulsória de medicamentos mostra-se como uma resposta adequada. Trata-se, afinal, de um edifício jurídico hábil a traduzir a necessidade interna do acesso a remédios essenciais em uma legítima possibilidade externa de utilização das flexibilidades previstas no TRIPS. Em outras palavras, traduz-se como uma legítima política pública de Saúde.

Ocorre que a realidade fática não parece comprovar a supremacia dos Direitos Humanos em relação às normas de comércio internacional, que parecem reproduzir a lógica da pobreza e da exclusão social, ao privilegiarem os interesses político-econômicos de atores governamentais e não governamentais (particularmente as farmacêuticas multinacionais). ${ }^{106}$

Imperativa, destarte, parece ser a formação de um forte envolvimento do setor público, articulando um efetivo instrumento de pressão que reúna a sociedade civil com o escopo de se gerar alguma sensibilização pública ao problema, obstando a reprodução da lógica da pobreza e exclusão, a impor barreiras à realização do direito ao desenvolvimento.

A pressão civil pública mundial, dessa sorte, deve ser realizada pela comunidade internacional, a partir de um agir conjunto e de uma resistência coletiva à violação de Direitos Humanos, para dialogar com Hannah Arendt. ${ }^{107}$ Afinal, o paulatino processo de adensamento de juridicidade ${ }^{108}$ porque passaram os Direitos Humanos comprova a força do public sentiment based on a wishful thinking, seja no âmbito da pressão doméstica, seja na perspectiva da pressão exercida pela comunidade internacional, mediante a figura do Power of Embarrassment. Deve, pois, a comunidade internacional clamar por uma consistente modificação da estrutura do processo econômico do mercado de fármacos essenciais, envolvendo a produção, a distribuição e o consumo das referidas

\footnotetext{
${ }^{106}$ LAFER, Celso. O Cenário Mundial e o relacionamento União Européia/Mercosul. Política Externa, v. 9, n. 1, p. 88-91, jun/jul/ago, 2000.

${ }^{107}$ ARENDT, Hannah. Origens do Totalitarismo - Anti-Semitismo, Imperialismo, Totalitarismo. São Paulo: CIA das Letras, 2004. p. 30-36.

${ }^{108}$ LAFER, Celso. Resistência e Realizabilidade da Tutela dos Direitos Humanos no Plano Internacional no Limiar do Século XXI. In: AMARAL JR, Aalberto do; C. P. MOISÉS, (Orgs.). O Cinqüentenário da Declaração Universal dos Direitos do Homem. São Paulo: Edusp, 1999. p. 450.
} 
drogas, focalizando questões de relevância humanitária, de modo a influenciar decisões, concretizar projetos e reiterar a legitimidade da utilização das flexibilidades previstas no TRIPS, sempre no sentido de realizar o direito à saúde.

São Paulo, novembro, 2007.

\section{Referências}

ARENDT, Hannah. Origens do Totaliotarismo - Anti-Semitismo, Imperialismo, Totalitarismo. São Paulo: CIA das Letras, 2004.

ARZABE, P. H. M. O direito à proteção contra a pobreza e a exclusão social. 2001. Tese (Doutorado) - Faculdade de Direito, Universidade de São Paulo, São Paulo.

AZAM, G. Economie sociale: quel pari? Economie et Humanisme, n. 347, dec. 1998/jan. 1999

BASSO, Maristela; POLIDO, F. Propriedade intelectual e preços diferenciados de medicamentos essenciais: políticas de saúde pública para países em desenvolvimento. Coleção $A B I A$ - Políticas Públicas, Rio de Janeiro, n. 4, p. 10, 2005.

BENGOA, Jose. Pobreza e vulnerabilidad. Temas Sociales, Santiago, n. 10, p. 2, abr. 1996.

BM, World Development Report 2000/2001 - attacking poverty, p. 1. Disponível em:<http://web.worldbank.org/WBSITE/EXTERNAL/TOPICSEXTPOVERTY/ 0, contentMDK:20195989 pagePK:148956 piPK:216618 theSitePK:336992,00.html>. Acesso em: 15 jul. 2006.

COMPARATO, Fabio Konder. A afirmação histórica dos Direitos Humanos. 3. ed. São Paulo: Saraiva, 2003.

CORREA, C. M. Implementing national health policies in the framework oh the WTO agreements. Journal of World Trade, v. 34, n. 5, p. 90, 2000.

DALLARI, S. G. Os Estados brasileiros e o direito à saúde. São Paulo: Hucitec, 1995. p. 19-20. Disponível em: <www.dhnet.org.br/educar/redeedh/bib/dallari3.htm>. Acesso em: 08 jul. 2006.

DESTREMAU, Blandine. The systemic relations of the State and poverty. Amman: University of Bergen, CROP, 1999. Disponível em: < http://www.crop.org/publications/files/newsletter/ Newsletter_1999_4.pdf $>$. Acesso em: 08 jul. 2006.

FIERENS, Jacques. Droit et pauvreté: droits de l'homme, securité sociale, aide sociale. Bruxelas: Bruylant, 1992.

FURTADO, Celso. O mito do desenvolvimento econômico. Rio de Janeiro: Paz e Terra, 1994.

KOTHARI, R. Poverty - human consciousness and the amnesia of development. London: Zed Books, 1993. 
LAFER, Celso. Comercio, desarmamento e Direitos Humanos: reflexões sobre uma experiência diplomática. São Paulo: Paz e Terra.

- A identidade internacional do Brasil e a política externa brasileira: passado, presente e futuro. São Paulo: Perspectiva, 2004.

. Liberdade e igualdade: reflexões sobre o crescimento econômico e a democracia. In: Ensaios sobre a Liberdade. São Paulo: Perspectiva, 1980. p. 130-32.

. O Cenário Mundial e o relacionamento União Européia/Mercosul. Política Externa, v. 9, n. 1, p. 88-91, jun/jul/ago, 2000.

LAFER, Celso. Resistência e realizabilidade da tutela dos Direitos Humanos no plano internacional no limiar do século XXI. In: AMARAL JR, Alberto do; MOISÉS, Cláudia Perrone. (Orgs). $O$ Cinqüentenário da Declaração Universal dos Direitos do Homem. São Paulo: Edusp, 1999. p. 450 .

LOPES, Helger Marra; MACEDO, Paulo Brígido Rocha; MACHADO, Ana Flávia. Indicador de pobreza: aplicação de uma abordagem multidimensional ao caso brasileiro. In: Texto para Discussão n. 223. Belo Horizonte: UFMG/Cedeplar, 2003. Disponível em: <http://www.cedeplar.ufmg.br/ pesquisas/td/TD\%20223.pdf>. Acesso em: 08 jul. 2006.

OMS, WHO/EDM/2001.2:Globalization, TRIPS and access to pharmaceuticals, WTO Policy Perspectives on Medicines, n. 3, March, 2001, World Health Organization, p. 5-6. Disponível em: <www.who.int/medicines/pdf/trade6paper.pdf:>. Acesso em: 08 jul. 2006.

OIT, The Patterns and Causes of Social Exclusion, in Social Exclusion and Anti-Poverty Strategies, 1996. Disponível em: <http://www.ilo.org/public/english/bureau/inst/papers/synth/socex/index. htm\#ch2>. Acesso em: 08 jul. 2006.

PETERSMANN, Ernst-Ultrich. Human rights and international economic law in the 21ST Century

- The need to clarify their interrelationships. Journal of International Economic Law, Oxford University, p. 10, 2001.

PNUD, Poverty Report 2000: overcoming human poverty, p. 20. Disponível em: <http://www.undp. org/povertyreport/ENGLISH/ARchap1.pdf> Acesso em: 08 jul. 2006.

RAWLS, John. Uma teoria da Justiça. 2. ed. São Paulo: Martins Fontes, 2002.

SACHS, I. S`attaquer aux raciness de l’exclusion. In: BRISSET, C. (Org.). Pauvretés. Paris: Hachete, 1996.

SEN, Amartya. Desenvolvimento como liberdade. São Paulo: CIA das Letras, 2002.

SKIRBEKK, G. A. St. Clair. A philosophical analysis of the World Bank's conception of poverty. Disponível em: <www.crop.org.wdasun.htm>. Acesso em: 01 jul. 2006. 